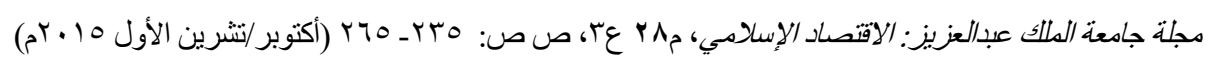
DOI: 10.4197 / Islec. 28-3.7

مشروعيّة عمليات الإصدار الإسلاميّة المستندة إلى تجزئة الملكيّة

$$
\text { محيي الدين عدنان الحجار }
$$

محاضر - باحث في القانون المالي - جامعاة بانتون سوربون - فرنسار الدين

المستخلص: تشكل هذه الورقة أرضية مشتركة للحوار بين

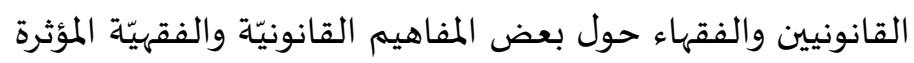

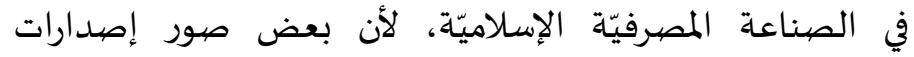

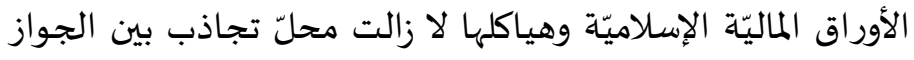

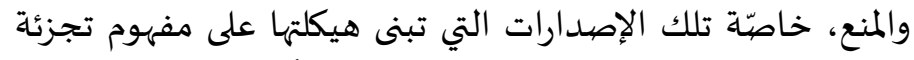

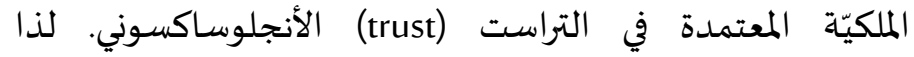

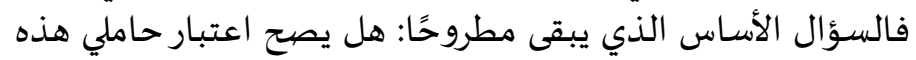

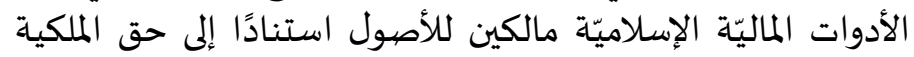

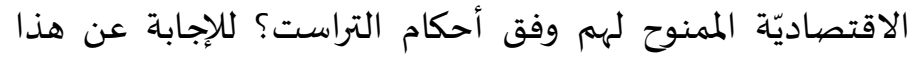

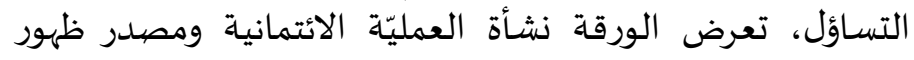

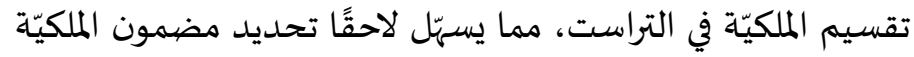

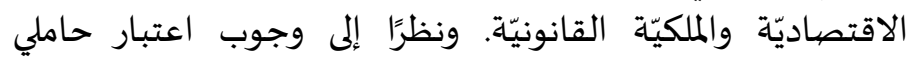

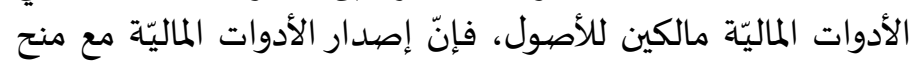

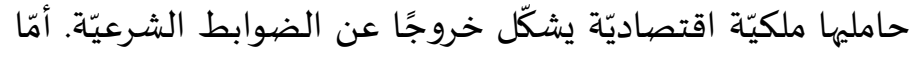

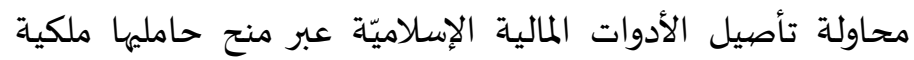

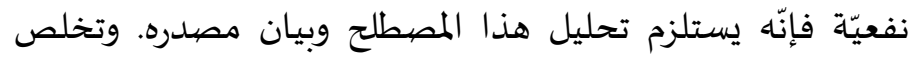

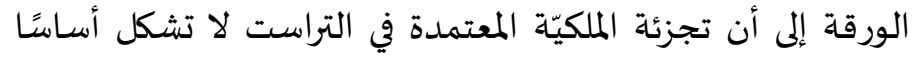

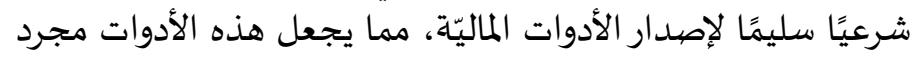

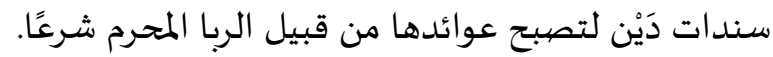

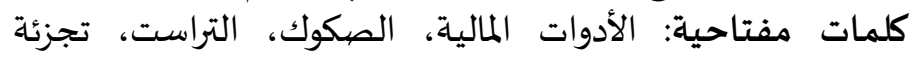
الملكية، التمويل الإسلامي. مفئة الادوات 


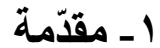

كلّ محاولة لتطبيق علاقة قانونيّة غريبة عن النظام القانوني الخاص بها إنها

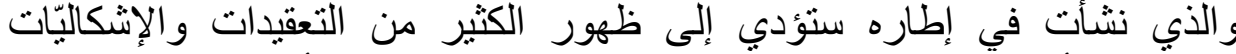
القانونيّة. لأنّ هذه العلاقات القانونيّة ستطرح الكيّة الكثير من الأسئلة حول التناسب

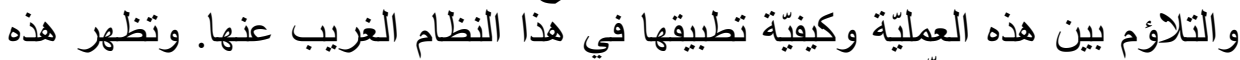

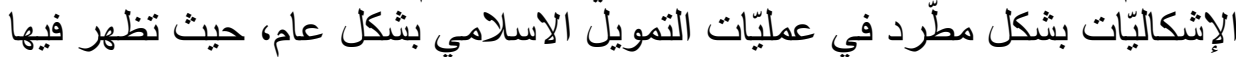

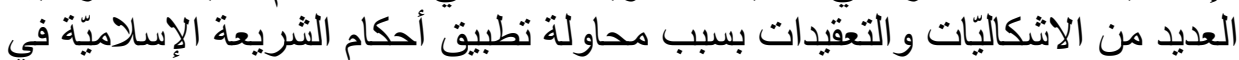

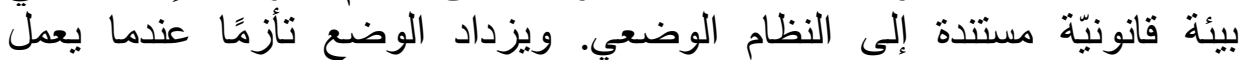

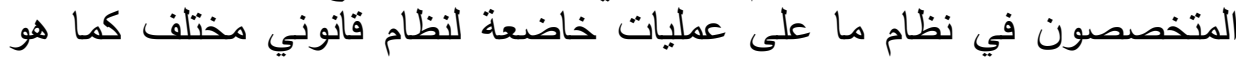

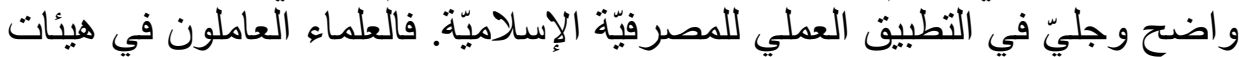
الرقابة الثرعيّة يفتقرون إلى المعرفة التقنيّة العميقة وبخاصيّة القانونيّة، وفي الإنيّة المقابل

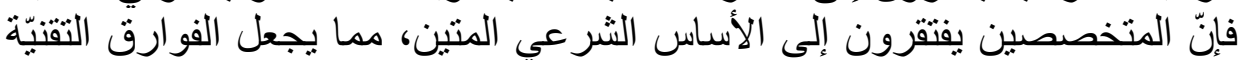

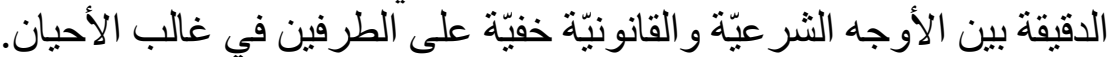

وقد ظهر في الآونة الأخيرة جدال طويل حول مشرو عيّة تأصيل عمليات

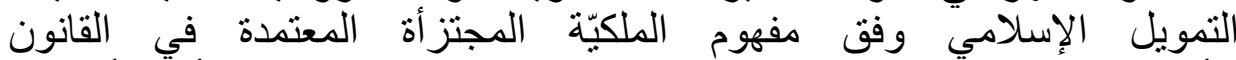

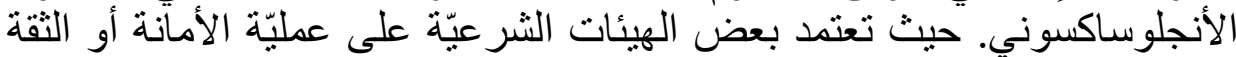
"التراست" المعروفة في هذا النظام القانوني و التي تؤدي إلى تئي تجزئة الملكيّة إلى التى

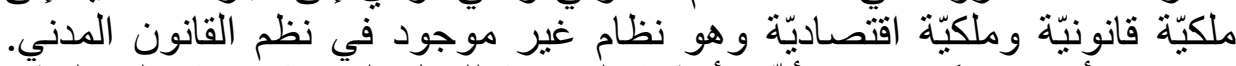

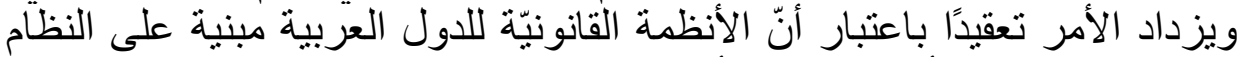

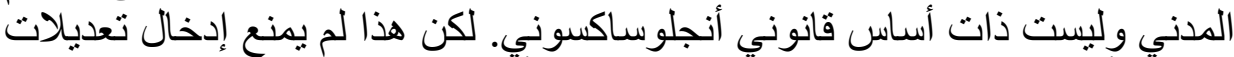

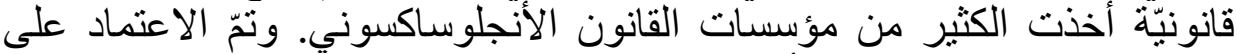

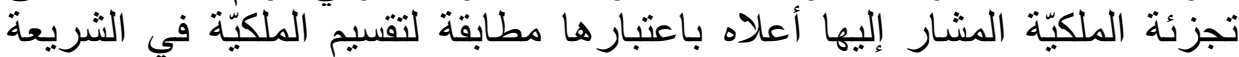

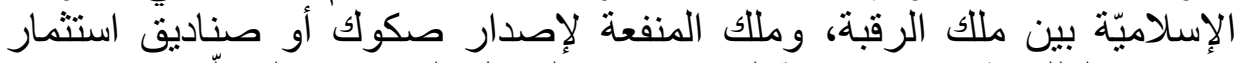

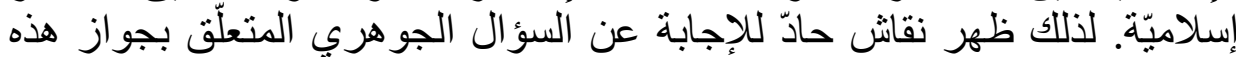
العمليات: هل يصح تأصيل العمليّات المالية الإسلاميّة على تجيَّئة تجزئة الملكيّة بين

اقتصاديّة وقانونيّة ولج

و الحكم على صحة هذا التأصيل الثر عي بيتلزم بدايةً معرفة طبيعة الملكيّة

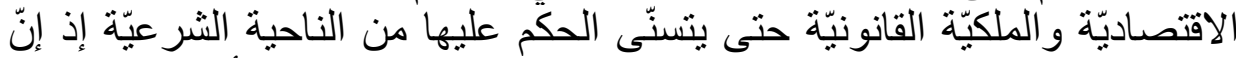

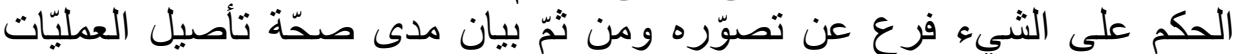

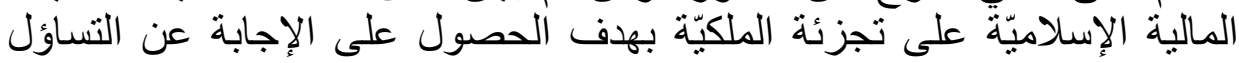
موضوع النقاشن.

ب ـ تطوّر العمليّة الائتمانيّة

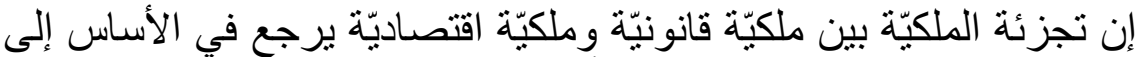

بدء ظهور عمليّة التراست في النظام الأنجلوساكسوني. لكنّ فهم حقيقة فيّة تجزئة 
الملكيّة في التر است الحديث يستلزم النظر في مصدر هذه التجزئة كما تكرّست في

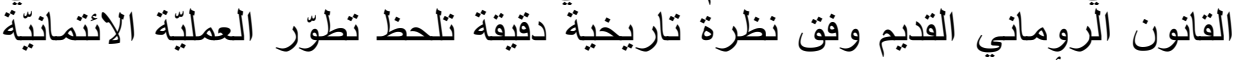

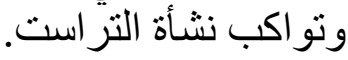

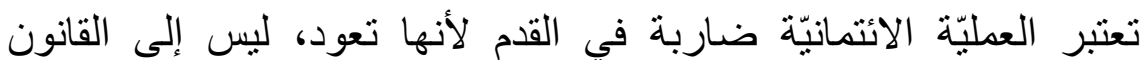

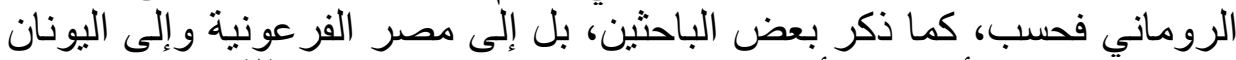

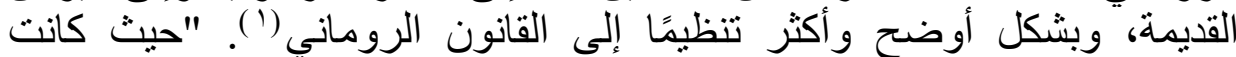

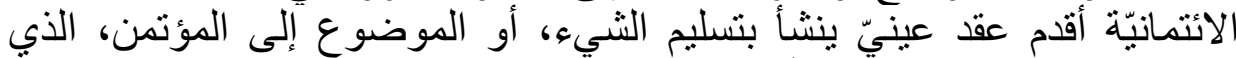

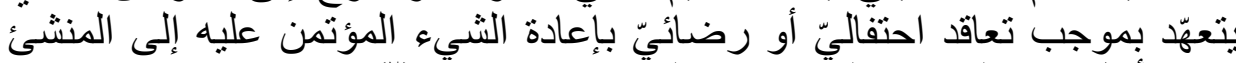

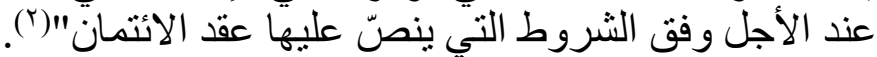

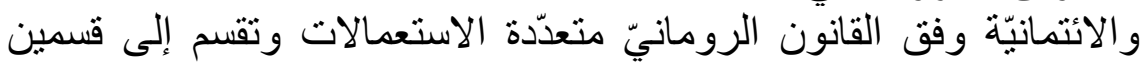

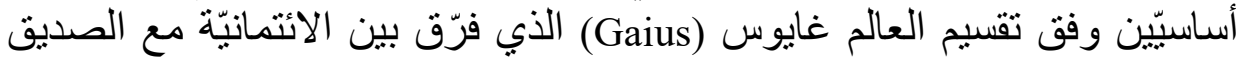
(Fiducia cum amico)

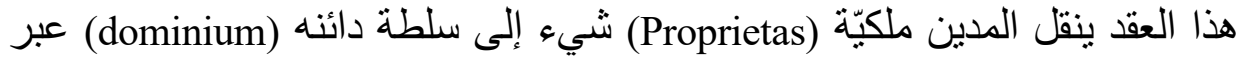

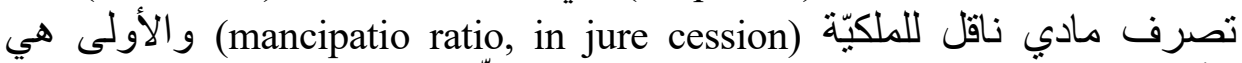

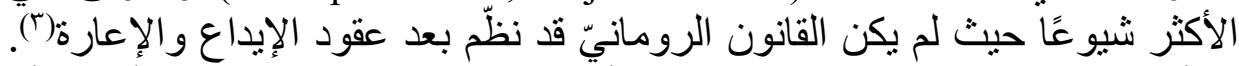

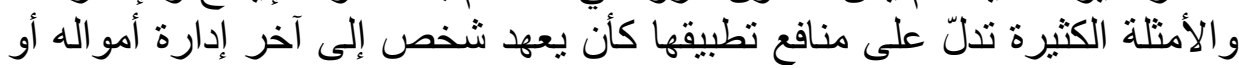

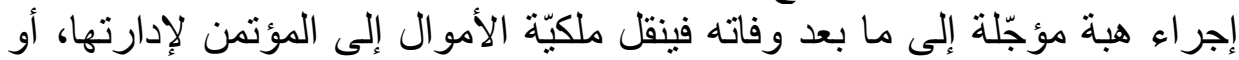

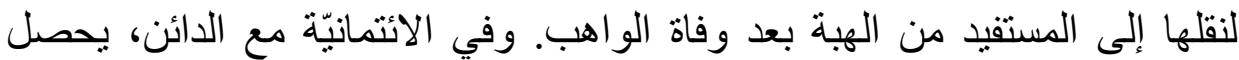

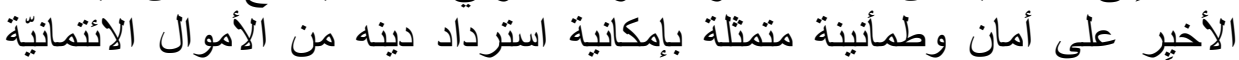

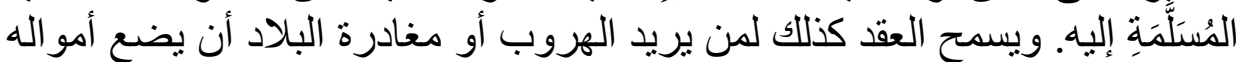

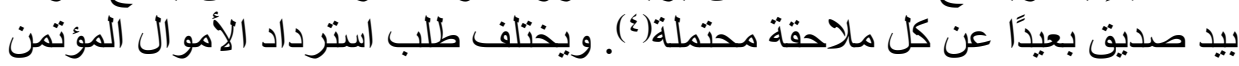
عليها تبعًا لغاية الائتمانيّة:

ـ الائتمانيّة على سبيل الاعارة : يقدم طلب الاسترداد بعد أن يكون المؤتمن قد استعمل الثيء. ـ الائتمانيّة على سبيل الايداع : يمكن للمودع أن يسترجع الأمو ال عند الطلب.

(1) P. Marini: « La fiducie enfin », in Dossier: La fiducie, JCPE 2007،2050, N7 ; et P. Marini: «Enfin la fiducie à la française », in dossier La fiducie, D2007, 1347.

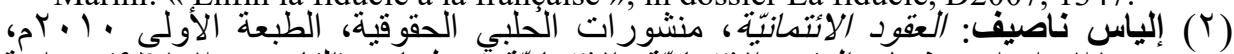

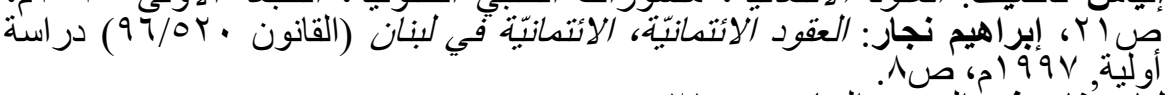

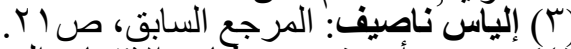

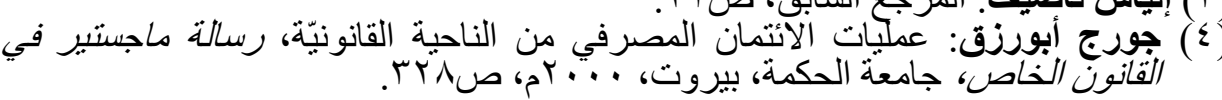




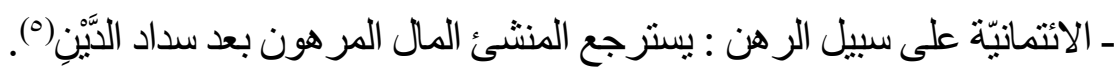

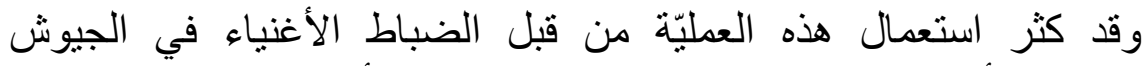

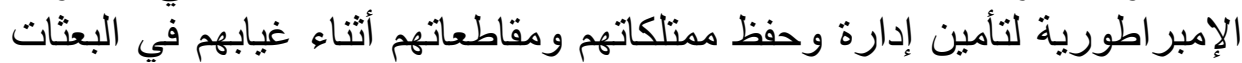

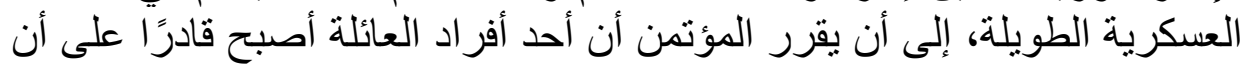

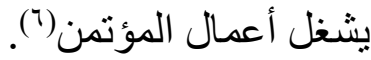

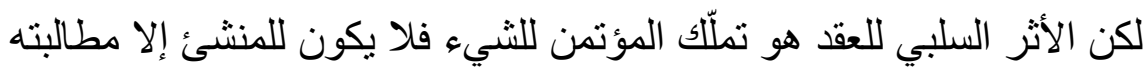

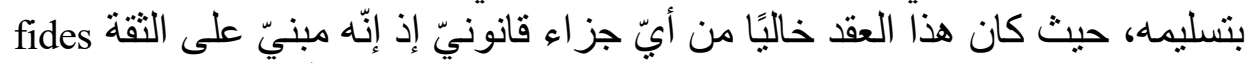

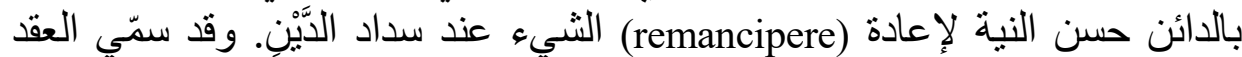

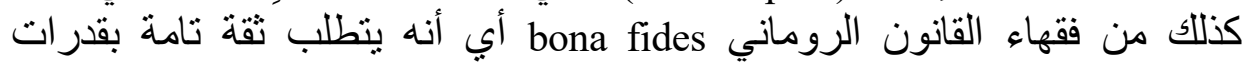

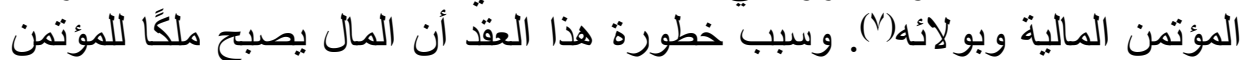

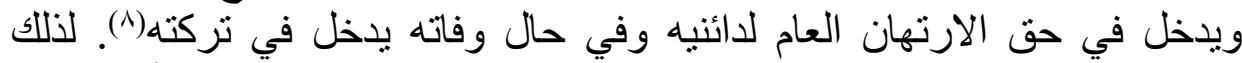

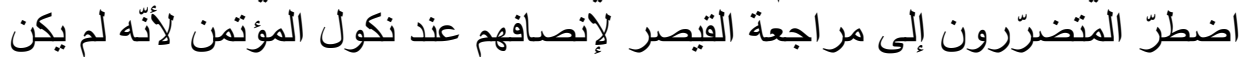

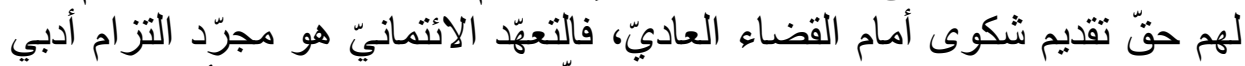

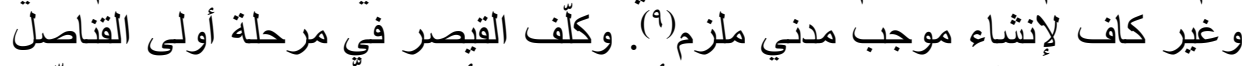

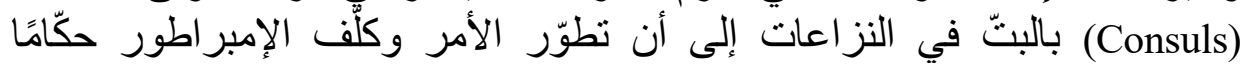

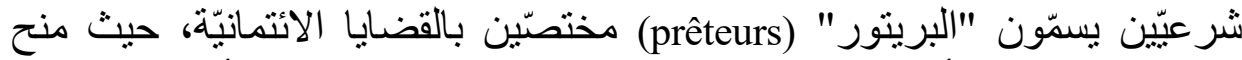

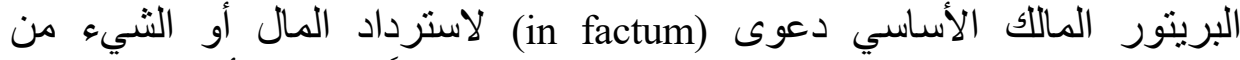

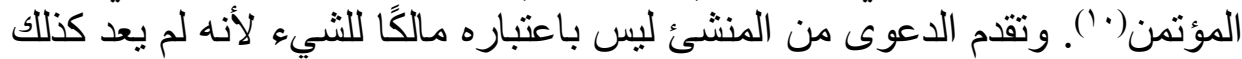

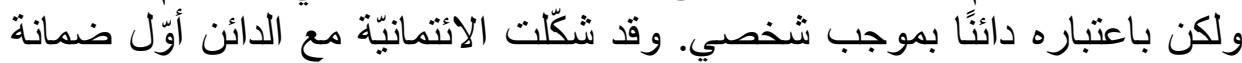

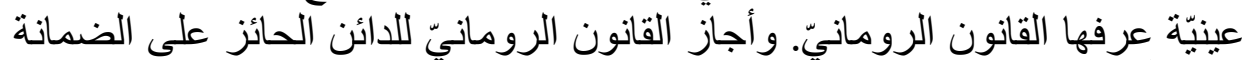

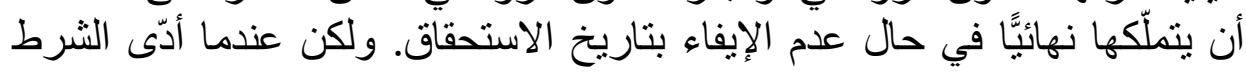

(5) J-P. Dom: « La fiducie-gestion et le contrat de société. Éléments de comparaison », Rev. Soc. 2007, p.481 N2.

(6) C. Champaud et D. Danet: «Sociétés et autre groupement », RTDCom 2007, p.728, N1.

(7) C. Champaud et D. Danet : « Sociétés et autre groupement », art.p. N1.

(8) C. Larroumet: La loi du 19 février 2007 sur la fiducie, Propos critiques, in dossier La fiducie، D2007, 1350، N5.

(9) J-P. Dom: «La fiducie-gestion et le contrat de société. Éléments de comparaison », art. p. N2 et les réf. mentionnées.

(10) J-P. Dom: « La fiducie-gestion et le contrat de société. Éléments de comparaison », art.p. N2. 
المعروف Commissoria Lex) إلى تجاوز (ات عمد الإمبر اطور قسطنطين إلى منعه

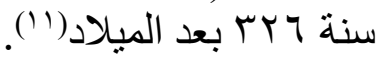

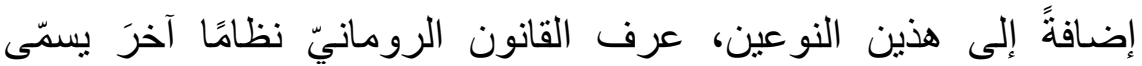

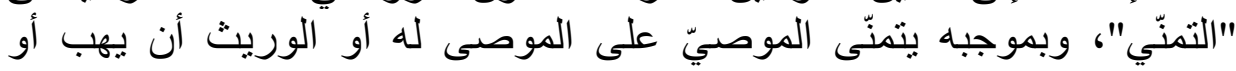

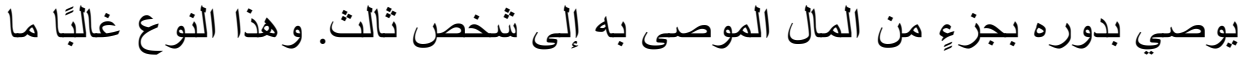

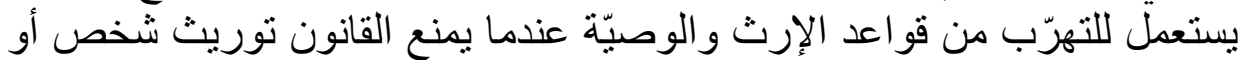

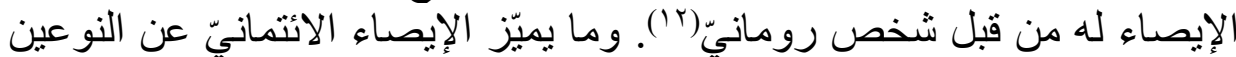

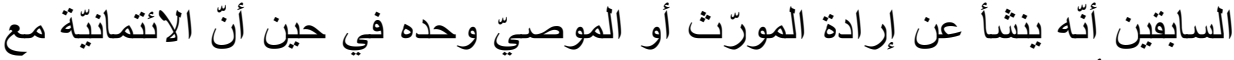

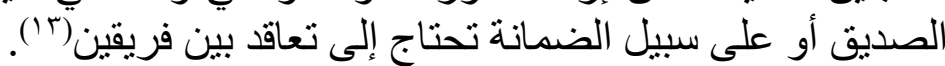

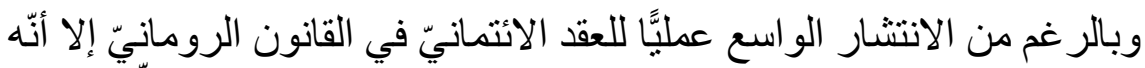

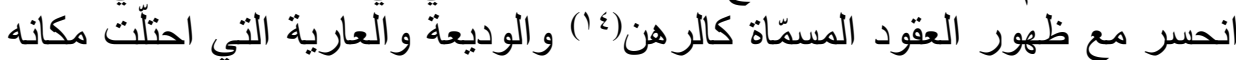

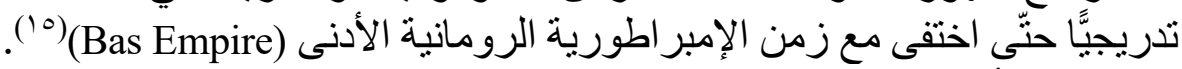

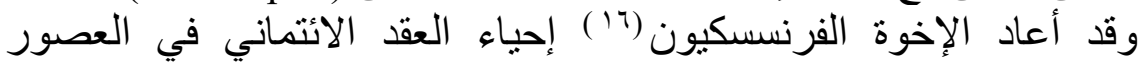

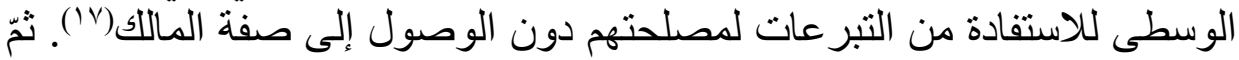
تم استعماله خلال هذه الفترة لاستبعاد أحد الورثنة من التركة خاصة التها البكر عندما

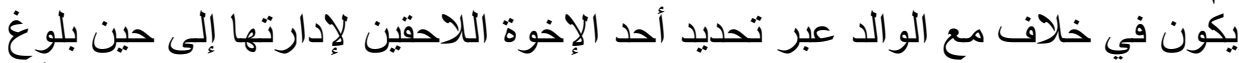
ابن الابن البكر، وكذلك لو كانت البنت هي البكر، وسمي الحلول الإيصائي؛ أي الإني

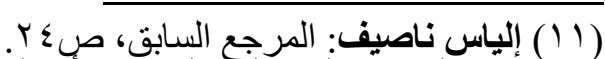

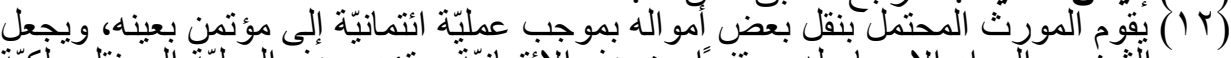

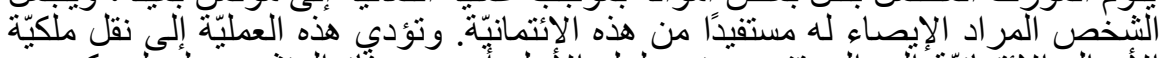

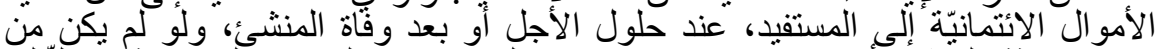

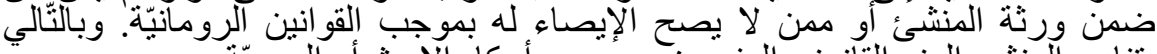

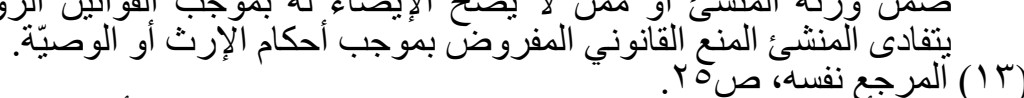

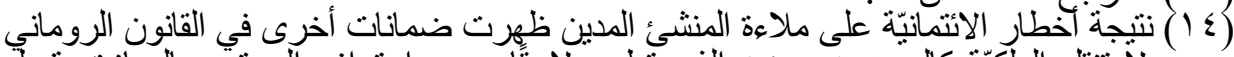

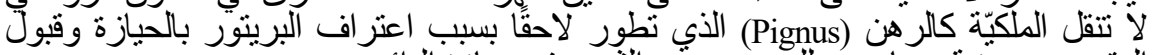

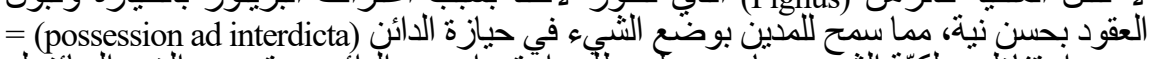

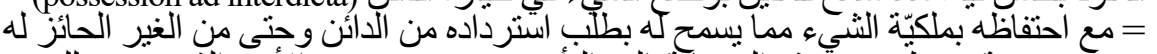

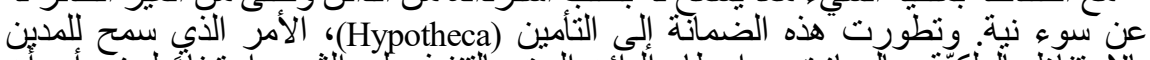

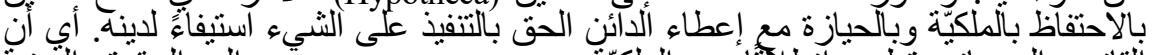

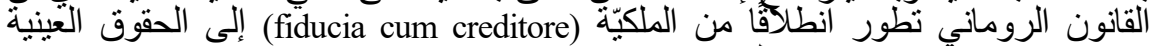

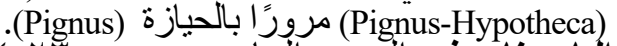

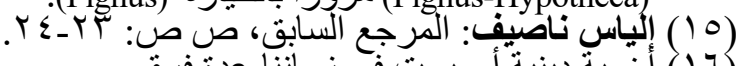

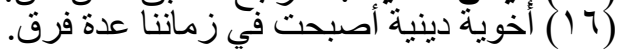

(17) J-P. Dom: « La fiducie-gestion et le contrat de société. Éléments de comparaison », art. p. N4. 
تعيين وريث شكلي للحفاظ على التركة ثم نقلها إلى الوريث الحقيقي(^)'. و واستمرّ

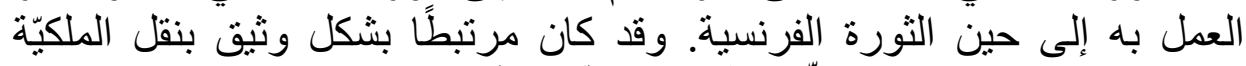

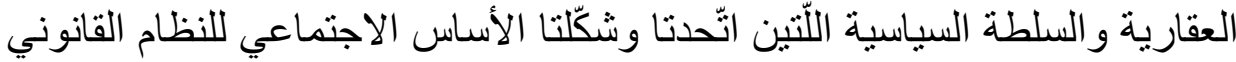

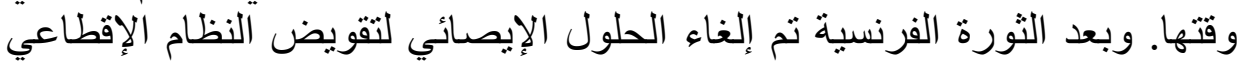

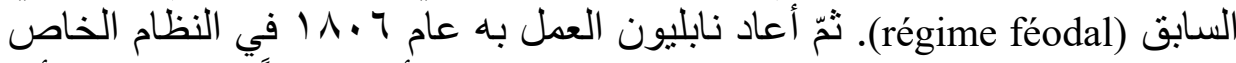

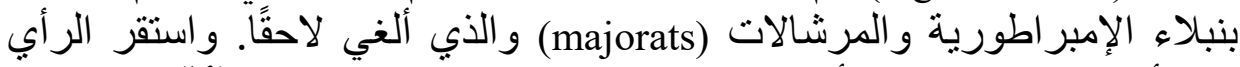

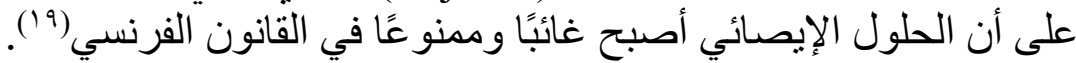

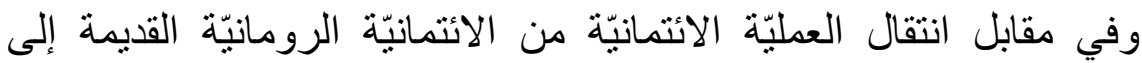

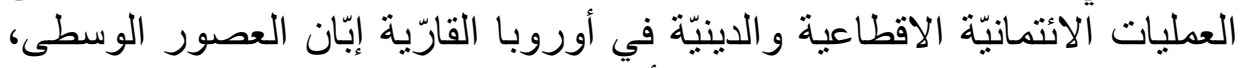

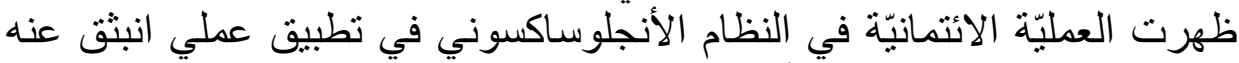

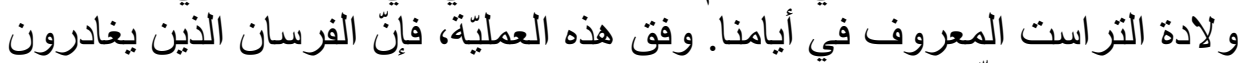

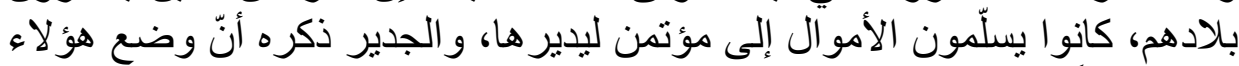

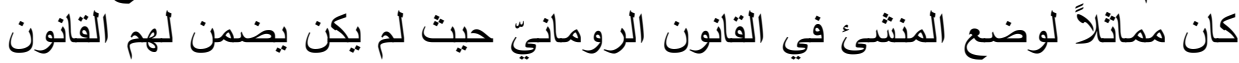

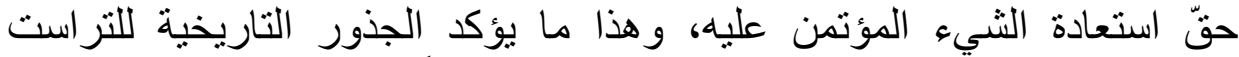

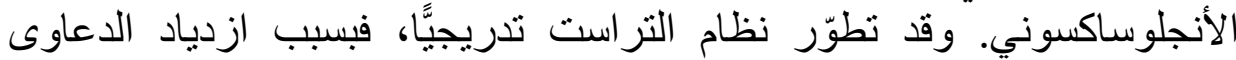

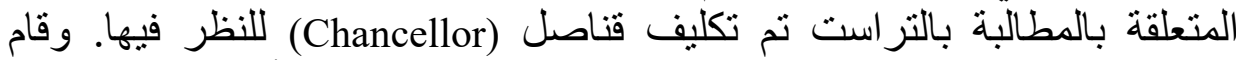

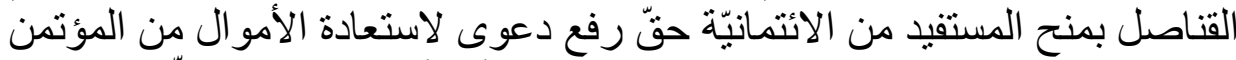

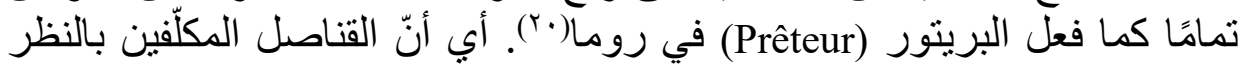

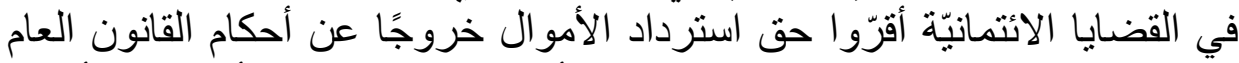

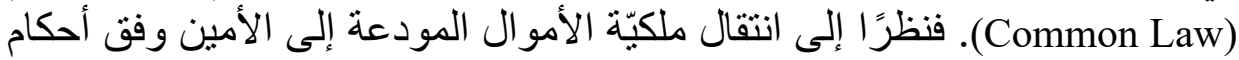

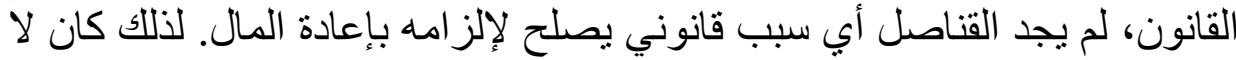

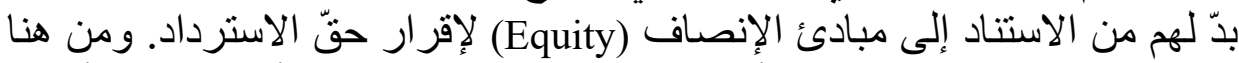

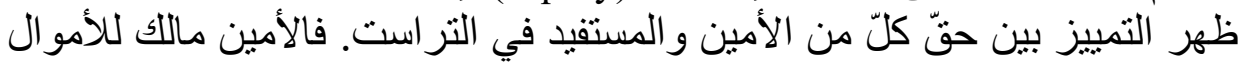

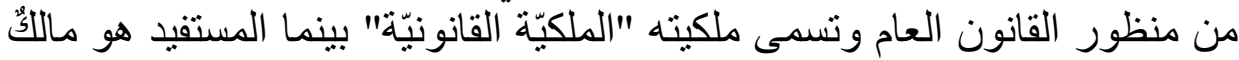

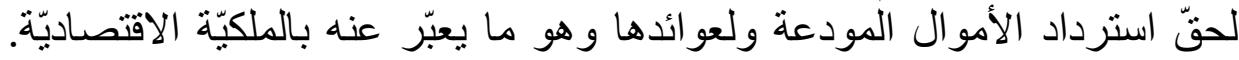

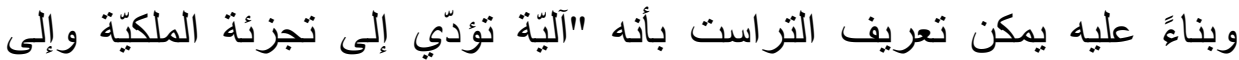

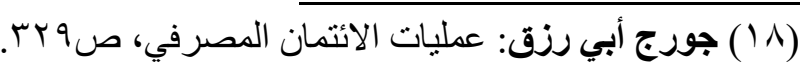

(19) J-P. Dom: «La fiducie-gestion et le contrat de société. Éléments de comparaison », art. p. N4. 
الاعتر اف للمؤتمن بالملكيّة القانونيّة (legal ownership)، بينما المستفيد يكون لله

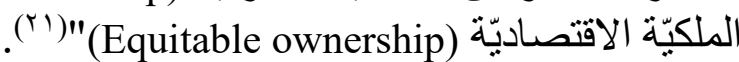

وقد تطوّر نظام التراست فاحتلّ مكانة مرموقة في التطبيق العملي بشكل

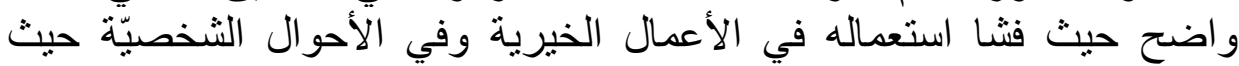
استعمل كأداة للتبرع و الإيصاء. لكنّه لم يقتصر على هذا المجال بل تصدر ميدان

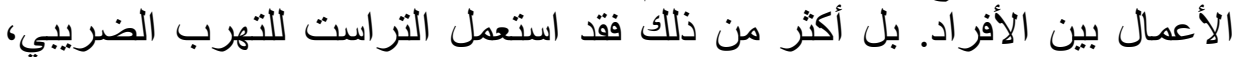

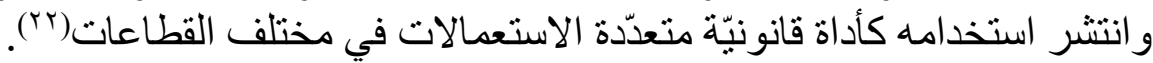
بـ مضمون الملكيّة القانونيّة والاقتصاديّة

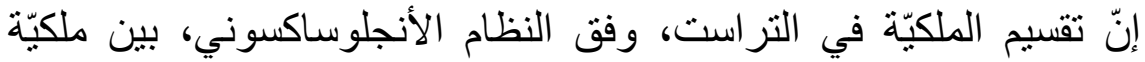
قانونيّة وملكيّة اقتصاديّة يسنلزم بيان طبيعة الحق الممنوح للمنشئ وذلك الممنوح

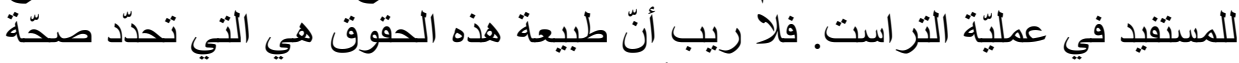
الوصف الثرعي للملكيّة الاقتصاديّة بأنها ملكيّة من منظور الثيّة هذهية الثريعة الإسلاميّة.

بالنظر إلى نشأة التراست وظهور الملكيّة المجزّأة، يظهر ارتباط التراست

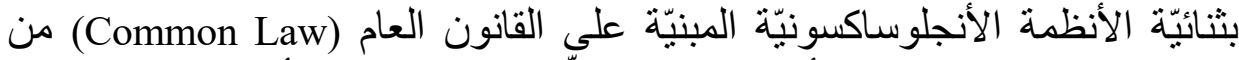

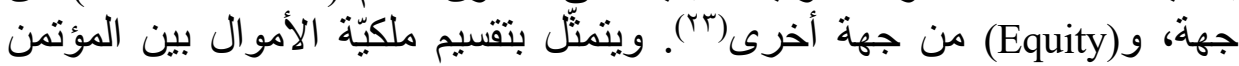
و المستقيد كالتالي:

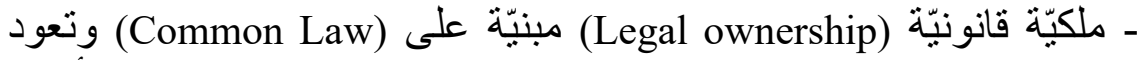

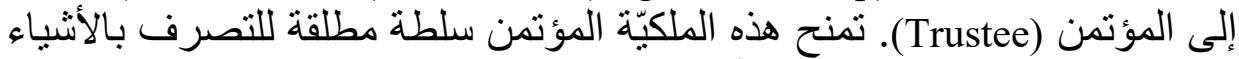

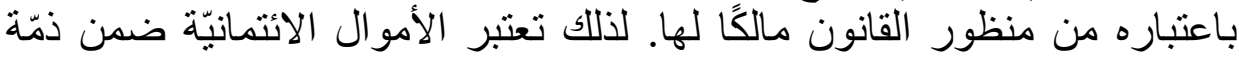
المؤتمن وتحت سلطانه المطلق، بل وكانت تدخل في تركته حين وفاته أو في التي

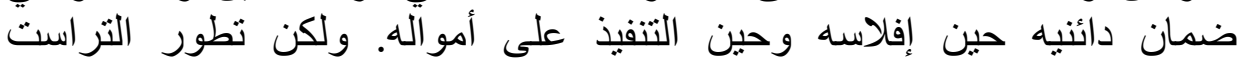

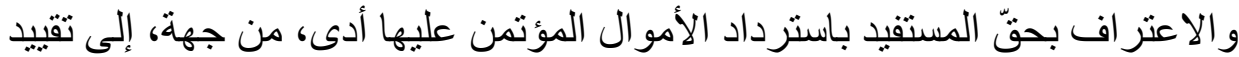

(21) F-X Lucas : « Les transferts temporaires des valeurs mobilières », LGDJ 1997, p. 276.

(22) C. Dergatcheff: "Droit comparé en matière de mécanisme fiduciaire: Pays Anglo-Saxons, Suisse, Luxembourg », in Dossier: La fiducie. JCPE, 2007, 2060, N5;

P. Marini: «La fiducie enfin », in dossier La fiducie, JCPE 2007 2050, N6 et

P. Marini: «Enfin la fiducie a la française », in dossier La fiducie, D.2007 1347.

(23) M. Graziadei, U. Mattei and L. Smith: « Commercial Trusts in European Private Law », Cambridge University Press, p.7. On line:

http://assets.cambridge.org/97805218/49197/excerpt/9780521849197_excerpt.pdf 


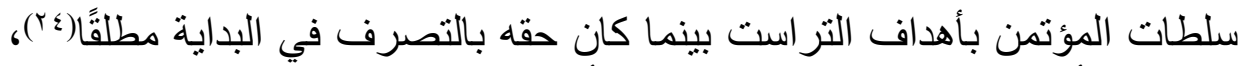
ومن جهة أخرى، إلى ارنباط مصنير هذه الأموال بحثّ المستفيد.

- ملكيّة اقتصاديّة (Equitable ownership) مبنيّة على الإنصاف (Equity)

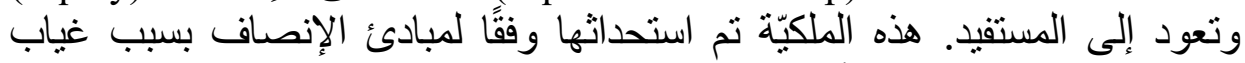

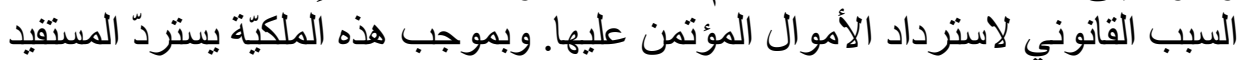

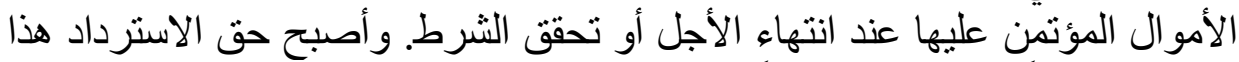

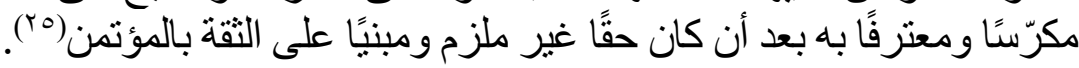

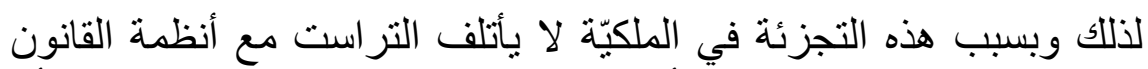

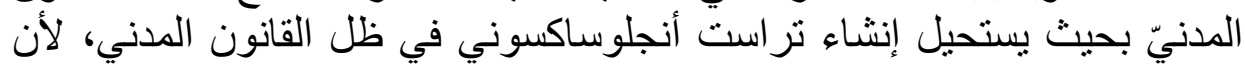

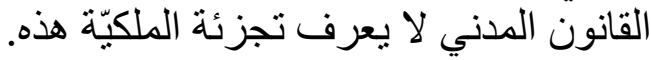

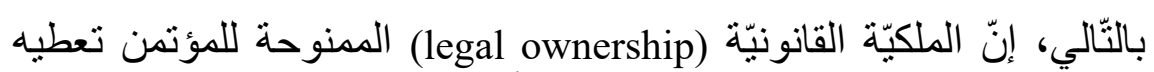

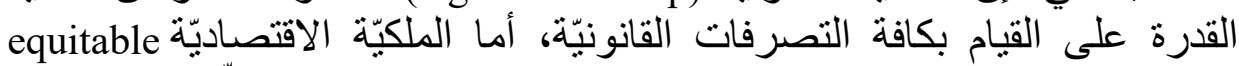
ownership

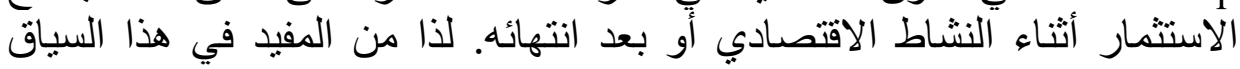

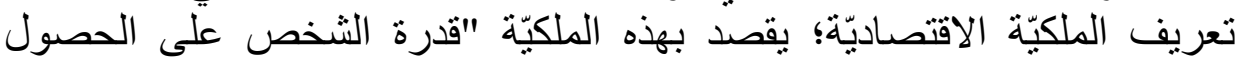

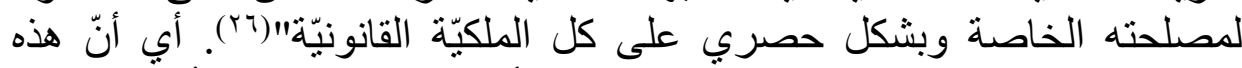

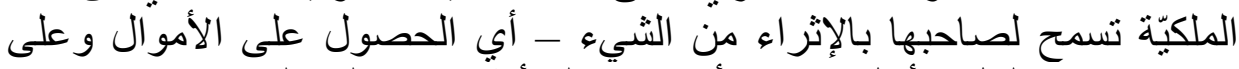

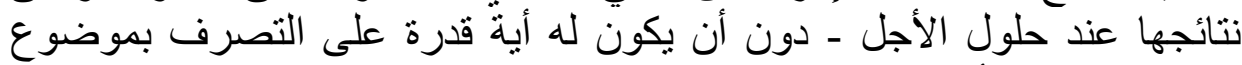

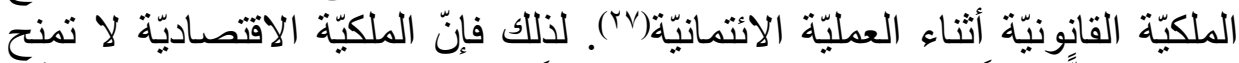

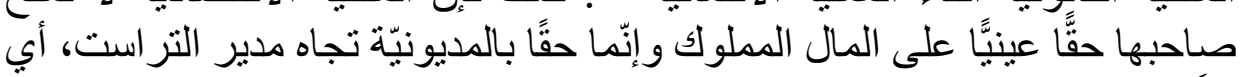

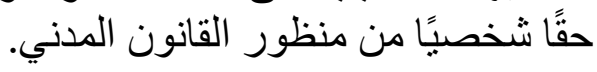

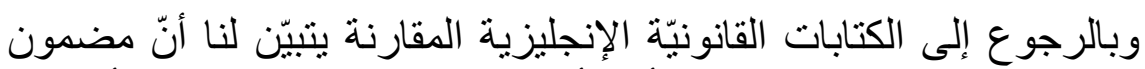

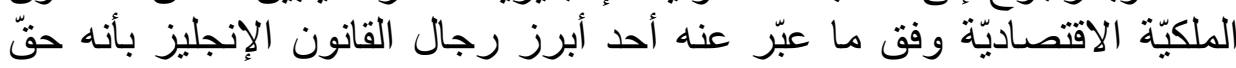

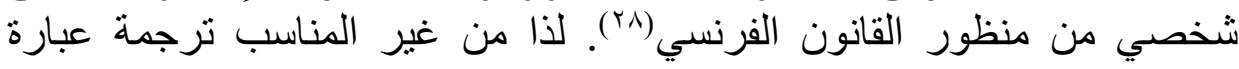

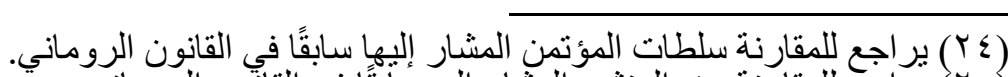

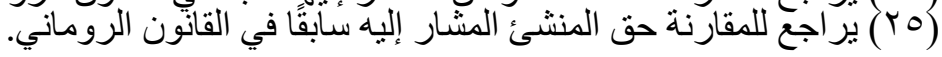

(26) F. Barrière: « Propriété, fiducie et sukuk », JCPE 2011.1203.

(27) L. Kaczmarek: «Propriété fiduciaire et droit des intervenants à l'opération », o.p. N14.

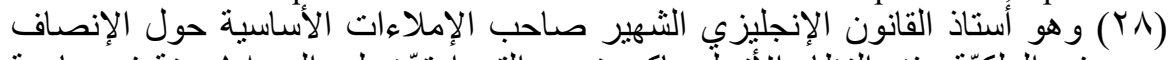

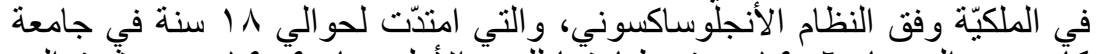

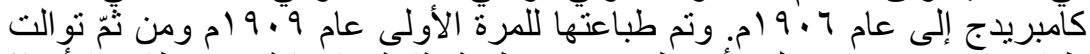

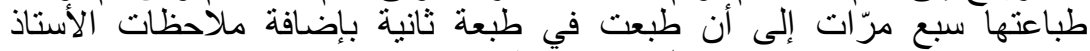
عام 49 (م و وهي التي تتكرر طباعتها حتى يومنا. 


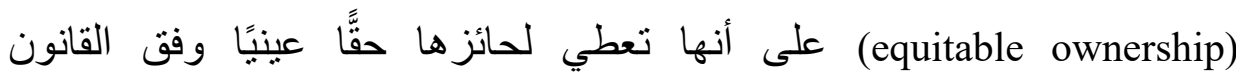

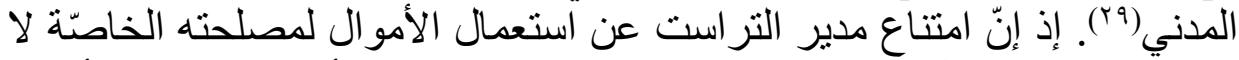

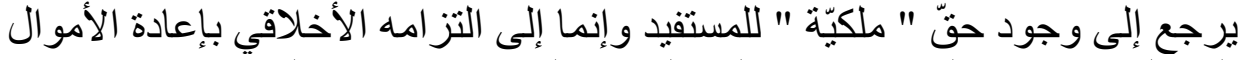

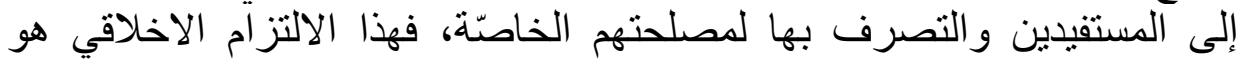

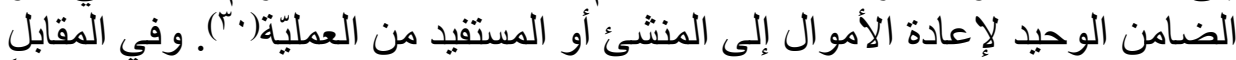

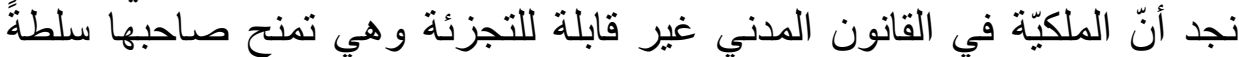

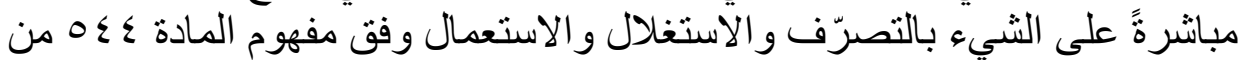
القانون المدني الفرنسي.

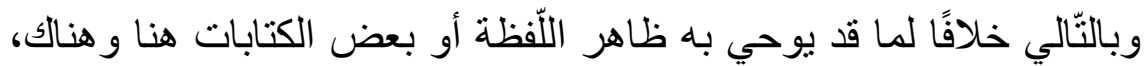

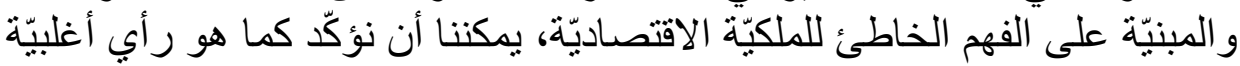

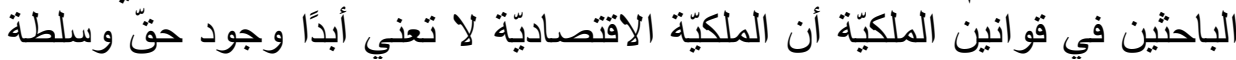

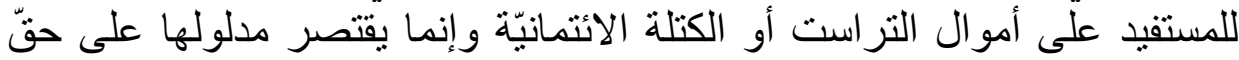
مديونيّة تجاه المدير يتمثل بالحصول على تللك الاموال وعو ائدها ونتائجها أثناء

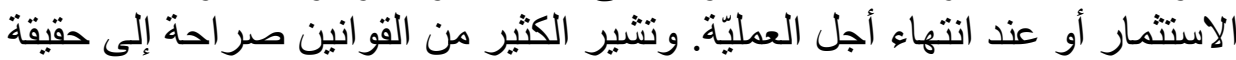

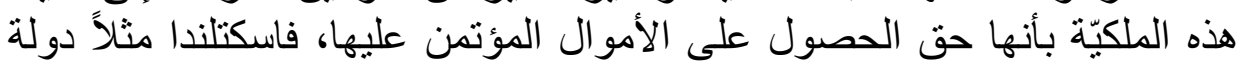

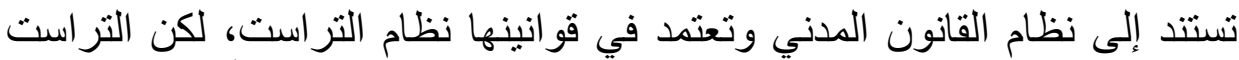

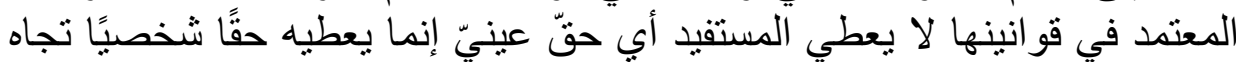

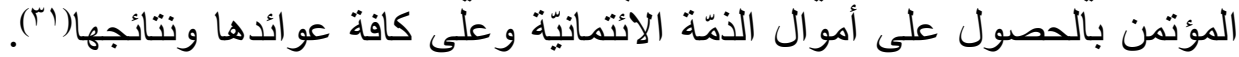

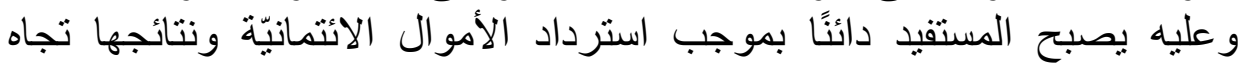
المؤتمن الذي بصبح مدينًا بهذا الموجبئ.

ع ـ ملكيّة الأصول كأبرز خصائص الأدوات المالية الإسدلاميّة

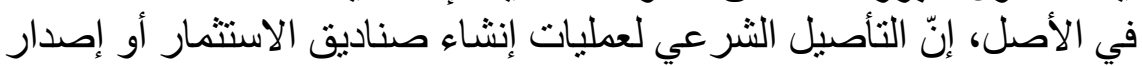

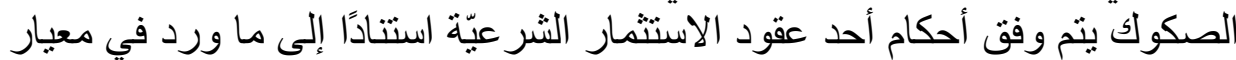

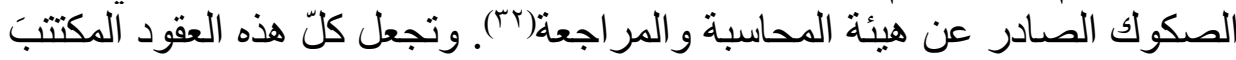
مالكًا للأصول التي يتم تمثيلها بالأوراق المالية المطروحة للاكتتاب بغض النظ هن النظر عن

F.W. Maitland: « Equity », Cambridge Univ. Press, 1936, 2nd éd., p. 17 \& p. 112.

(29) D.W.M. Waters: « The Nature of the Trust Beneficiary's Interest », 45 Can. Bar Rev., 1967, 219, p. 280.

(30) B. McFarlane: « The Structure of Property Law », Hart Publishing (Oxford), 2008, p. 580

(31) G. Gretton: « Trust Without Equity », 49 ICLQ 599, 2000.

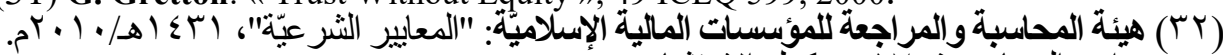

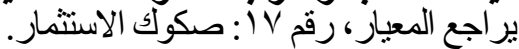


طبيعتها المادية من أعيان ومنافع وحقوق وديون وأور اق مالية. لذلك يجب أن يكون

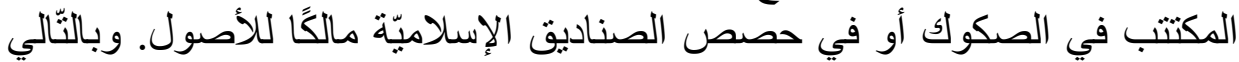
تكرّست هذه الملكيّة كإحدى خصائص المئس المنتجات المالية الإسلاميّة.

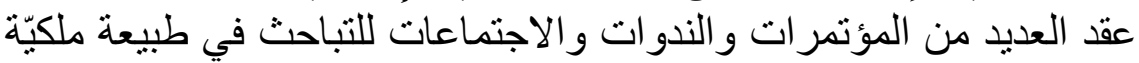

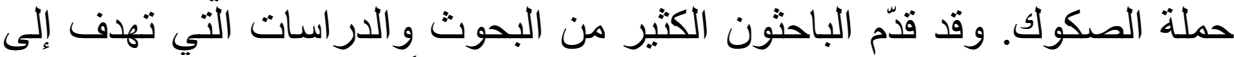

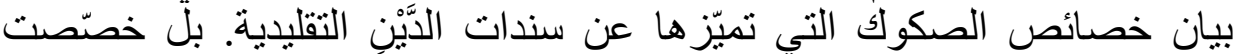

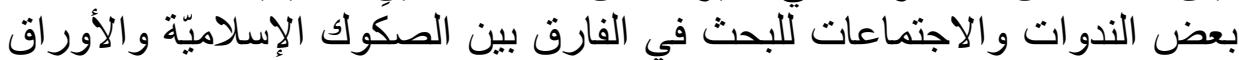

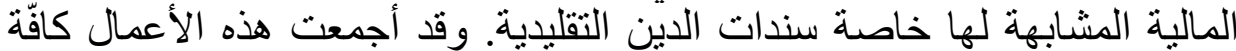

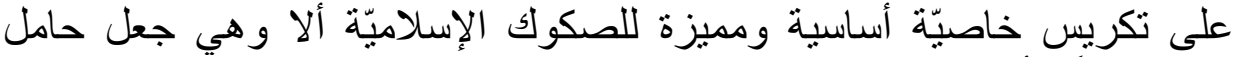

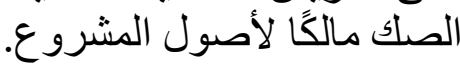

وتجدر الإنشارة إلى أن الملكيّة لفظ غير معروف في الثئ الثريعة، لكنّ العلاقة

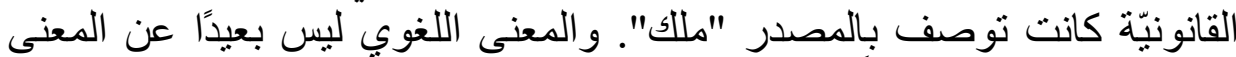

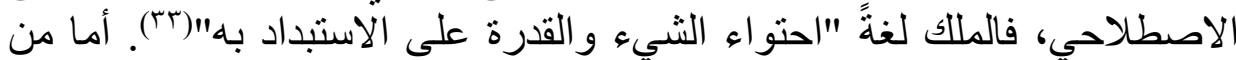

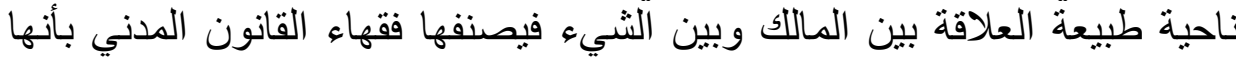

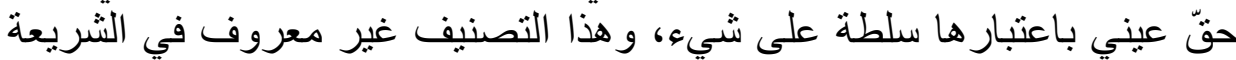

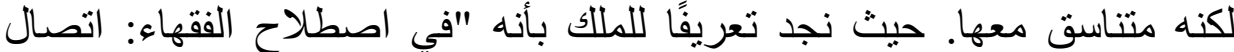

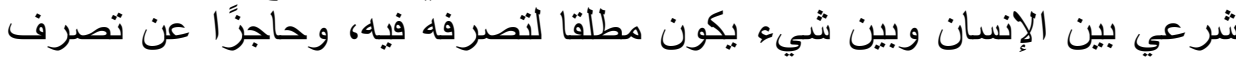

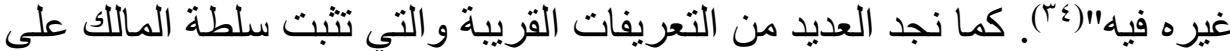

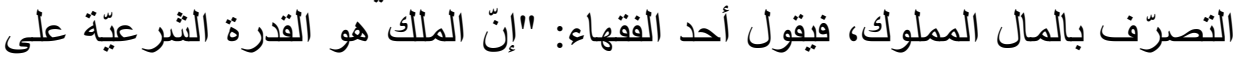

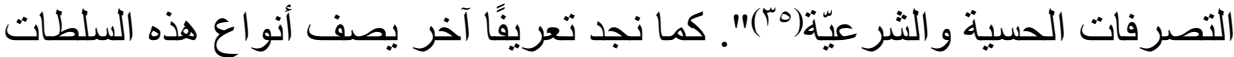

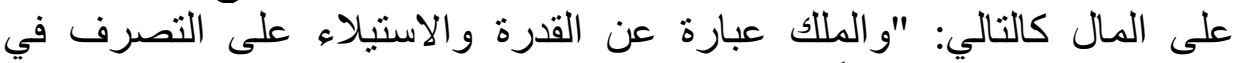

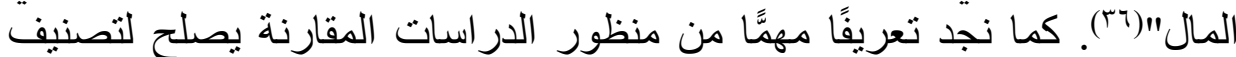

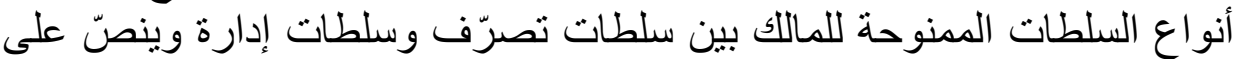

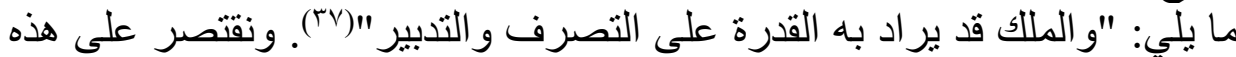

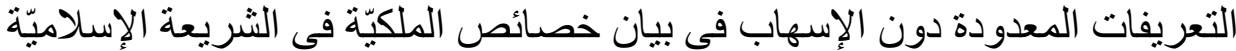

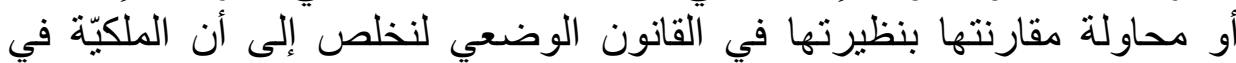

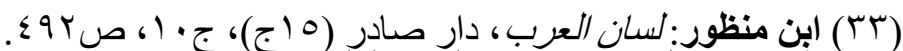

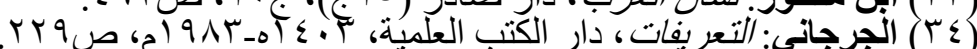

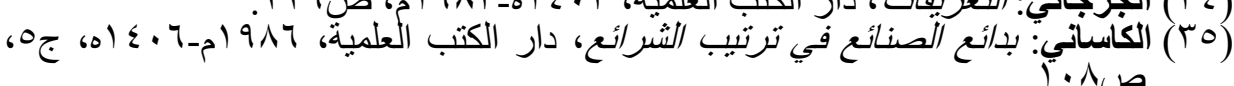

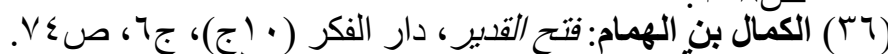

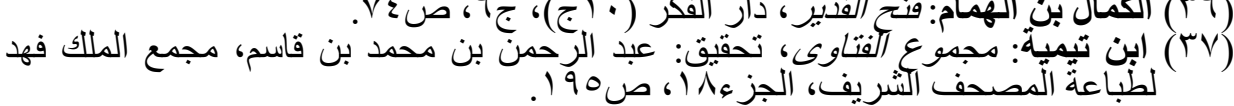


الثريعة الإسلاميّة تلتقي مع الملكيّة في القانون حيث تستلزم وجود سلطات فعليّة

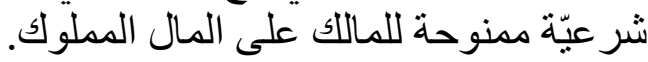

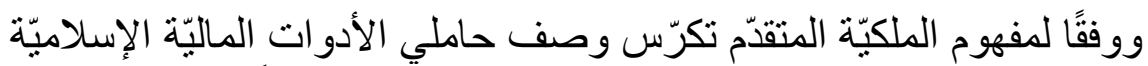

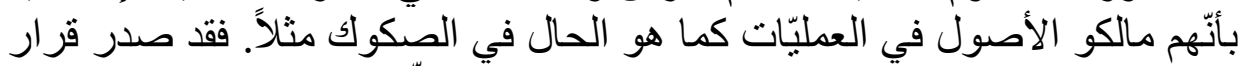

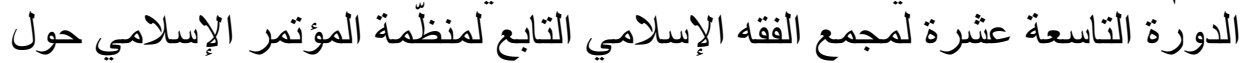

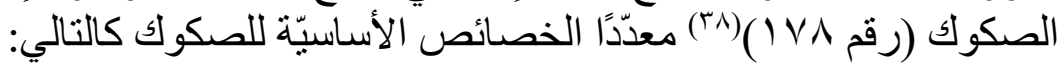

( ) يمثل الصك حصة شائعة في ملكيّة حقيقية.

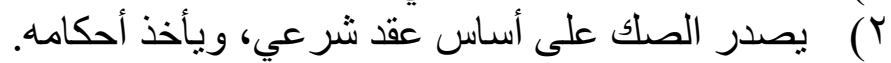
؟) انتفاء ضمان المدير (المضارب أو أو الوكيل أو الثريك المدير ).

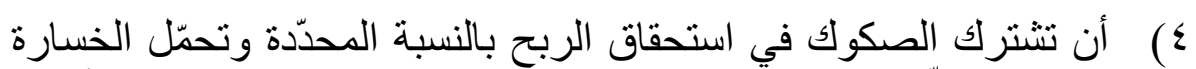

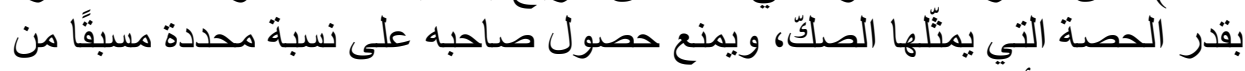
قيمته الاسميّة أو على مبلغ مقطوع. (1) ) تحمّل مخاطر الاستثمار كاملة.

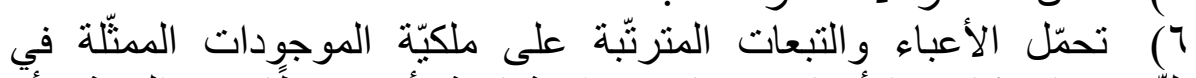

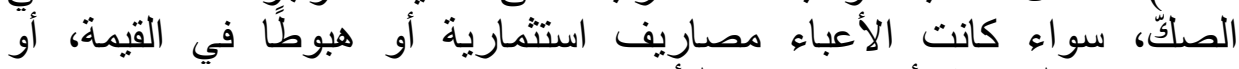
مصروفات الصيانة، أو اشتتر اكات التأمين.

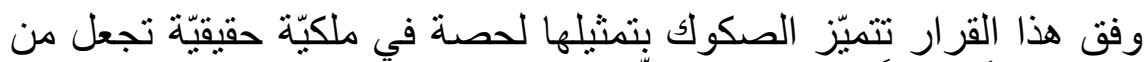

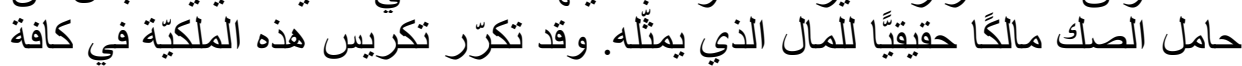

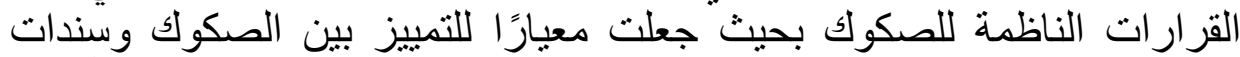

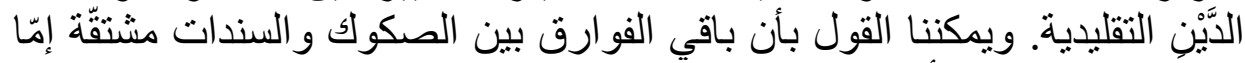

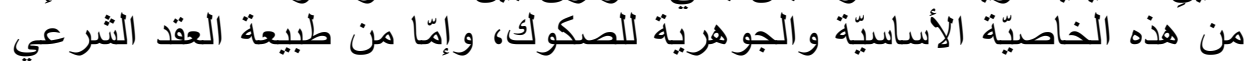

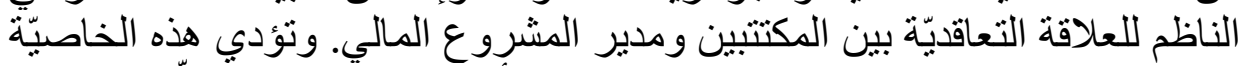

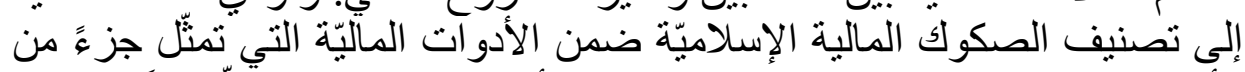

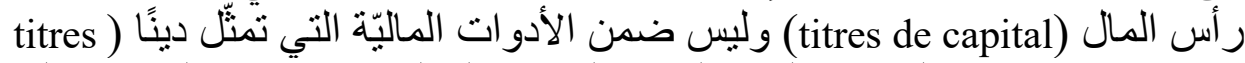

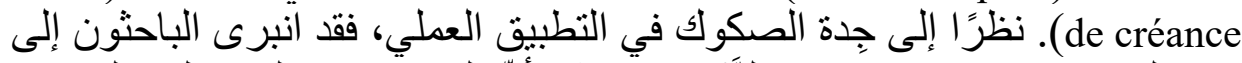

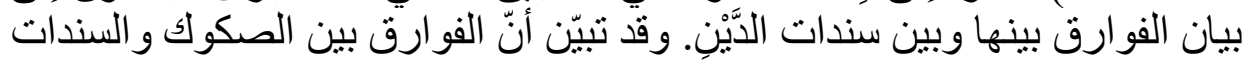

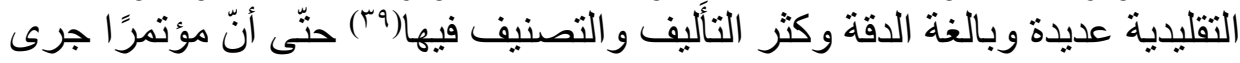

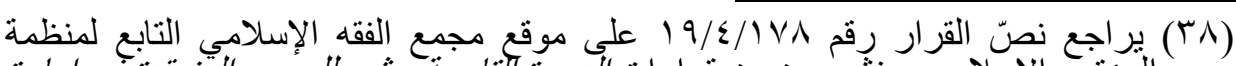

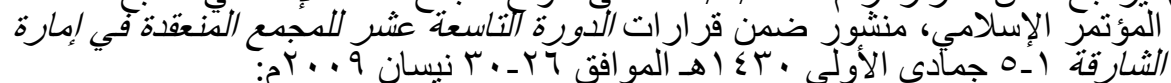
http://www.fiqhacademy.org.sa /

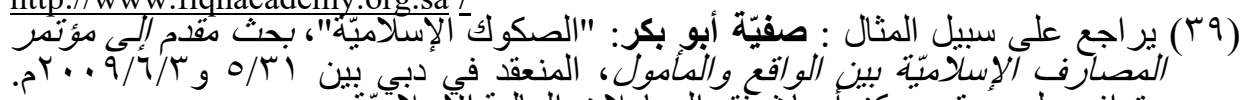

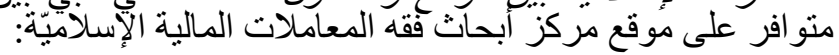


تتظيمه لبيان هذه الفوارق(·ء). وخلال هذا المؤتمر، تمّ الاعتر اف بملكيّة حملة

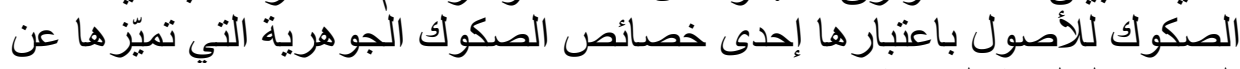
السندات التقليدية الربوية باعنبار

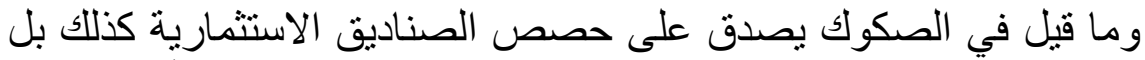

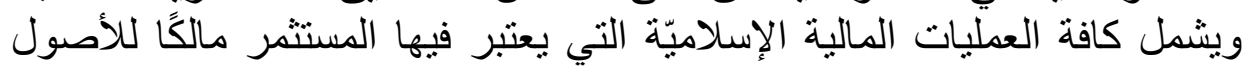

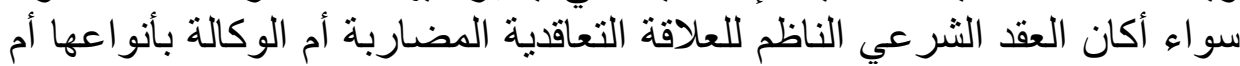

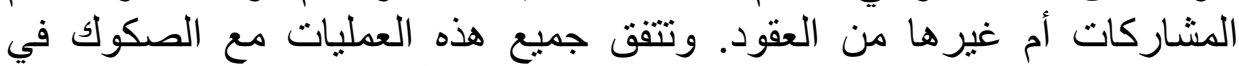

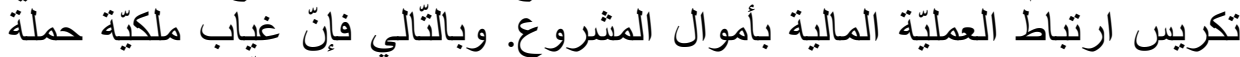

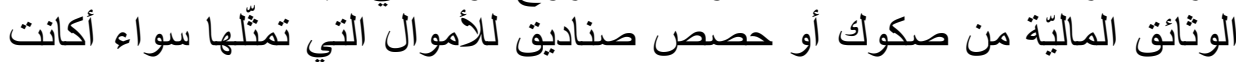

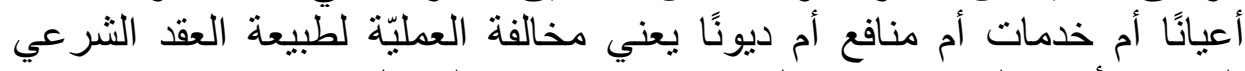

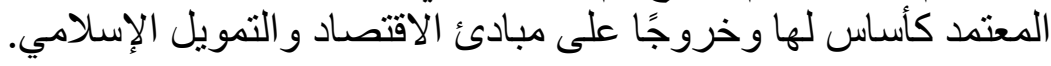

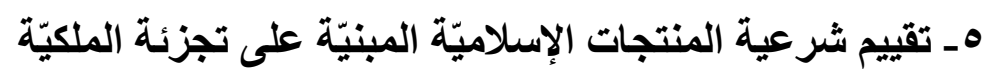

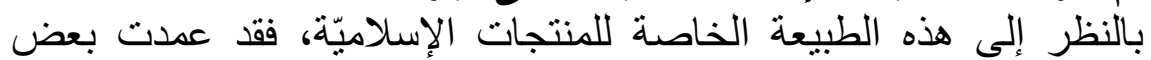

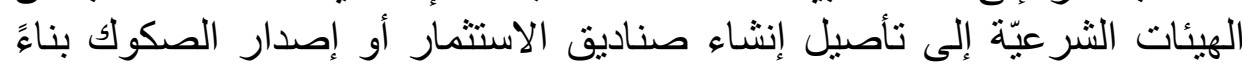

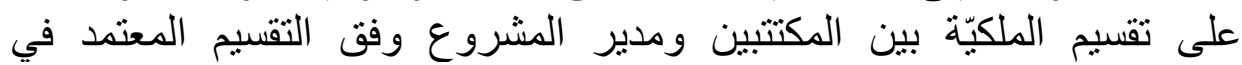

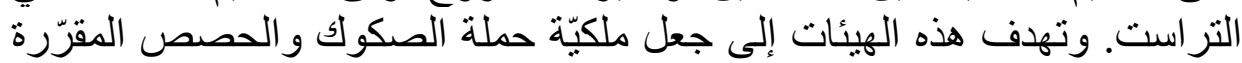

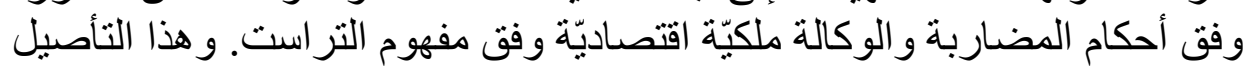

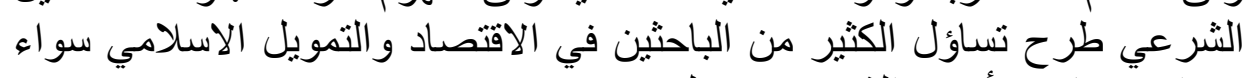

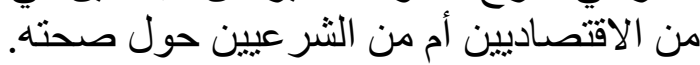

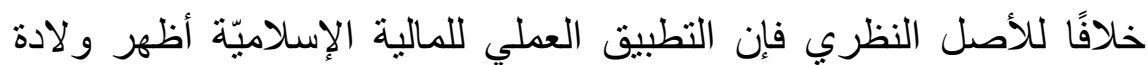

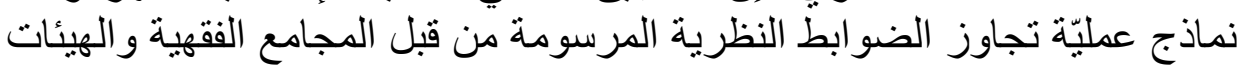

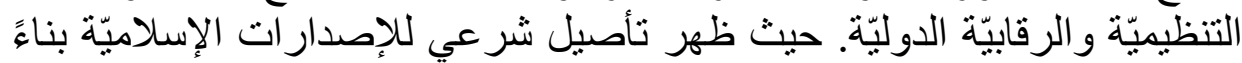

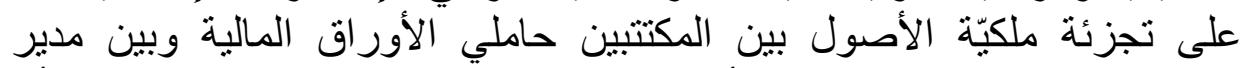

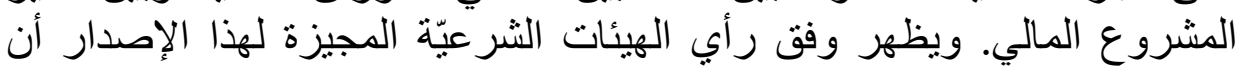

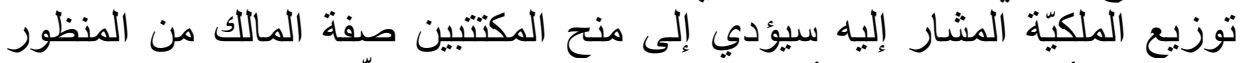

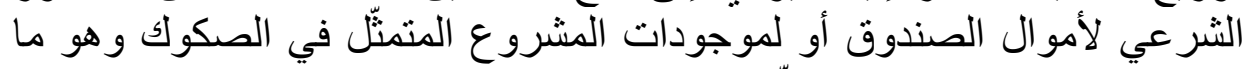

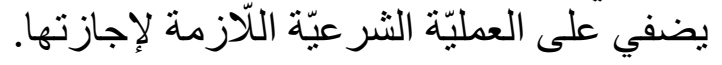

http://www.kantakji.com/figh/Files/Markets/m186.pdf

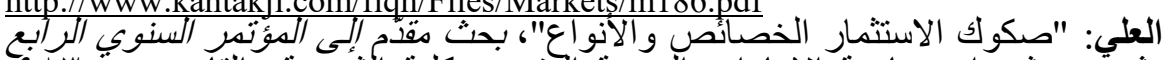

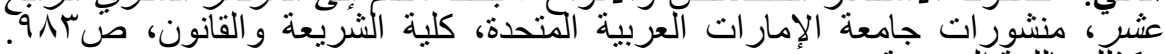
وكذنلك باللغة الفرنسية:

K. Jouaber-Snoussi: « La finance islamique », éd. La découverte Paris, 2012, p.106 et s.

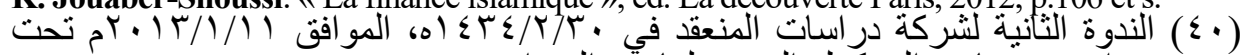

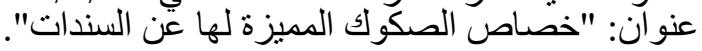


لكن في المقابل ظهر انتقاد شديد لهذه الممارسة حيث انتقد بعض كبار

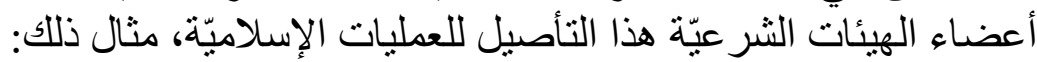

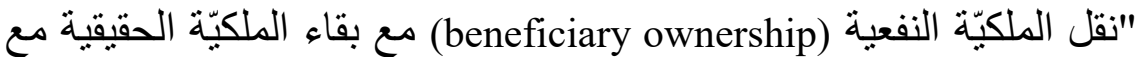

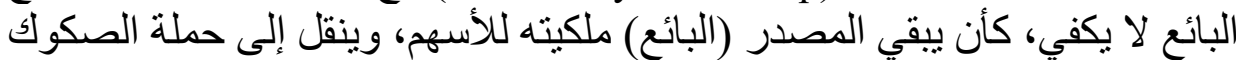

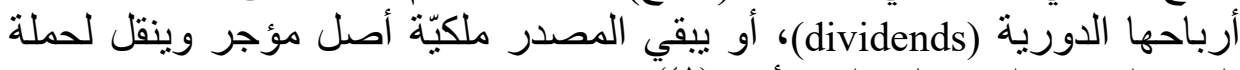

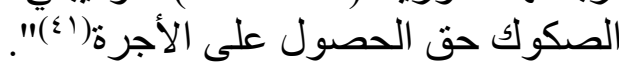

لذلك وفق هذا الاعتراض، الذي نؤيده بالكليّة، فان الملكيّة النفعيّة، التي التي

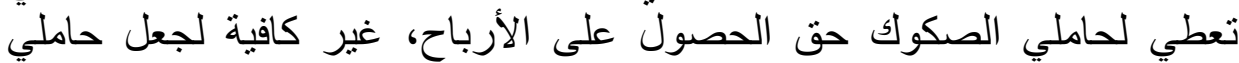
الأوراق المالية الإسلاميّة من صكوك وحص وحص صناديق الارباح، وغير ها مالكين للأصول.

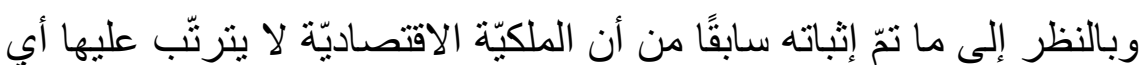

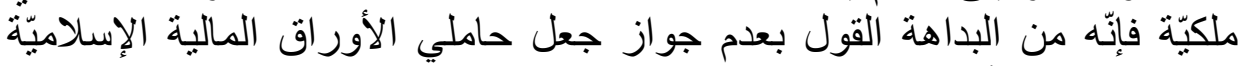

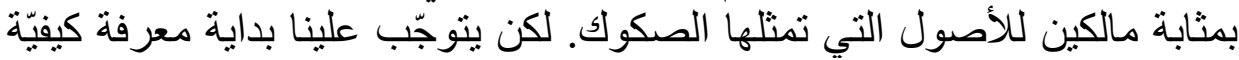

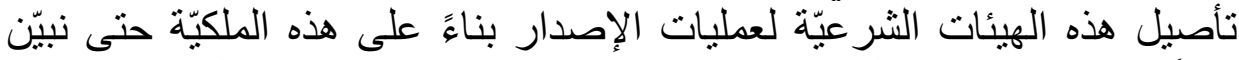

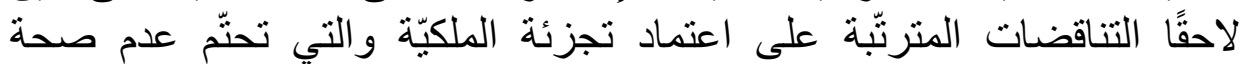

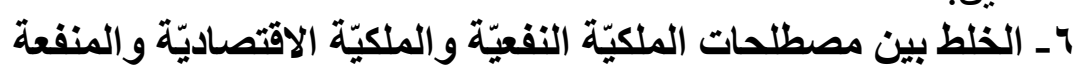

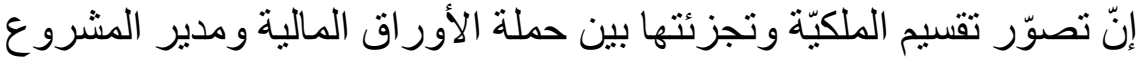

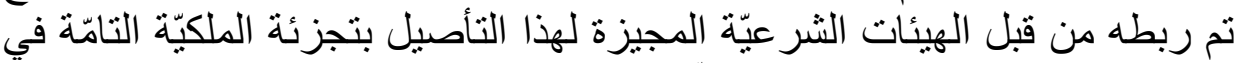
الثريعة بين الرقبة والمنفعة. وبالتّالي فإن مقارنة تجزئة الثئة الملكيّة بين النظامين

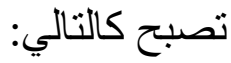
- مقابلة ملكيّة الرقبة للملكيّة القانونيّة المهنوحة للمؤتمن.

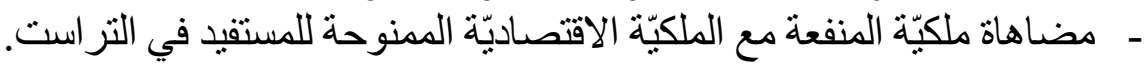

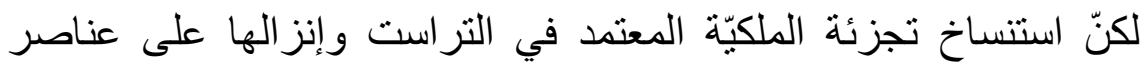

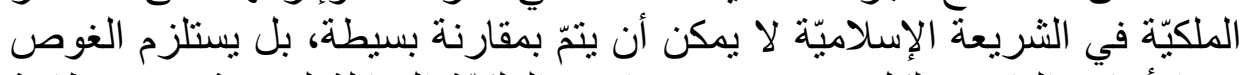

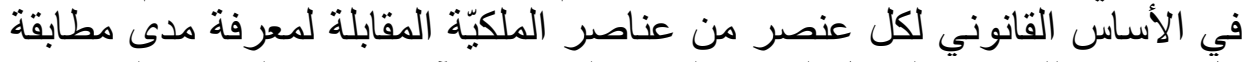

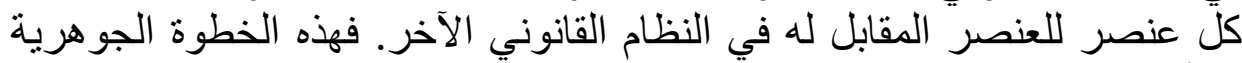

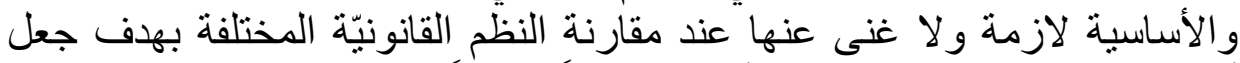
أحد المصطلحات المعتمدة في أحدها مقابلاً وبديلاً لمصطلح في النظام الآخر.

( ) حسين حامد حسّان: "لراسة حول موضو ع بعض جوانب الصكوك المعاصرة"، منشورة

http://www.hussein-hamed.com/pagedetails.aspx?id=112 


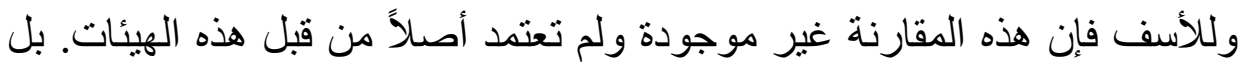

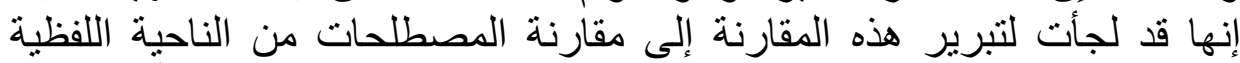

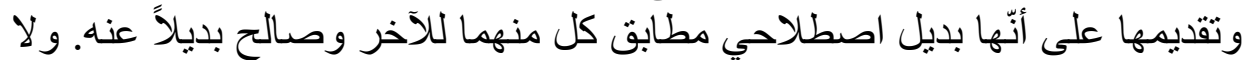

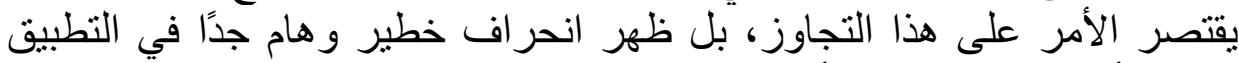

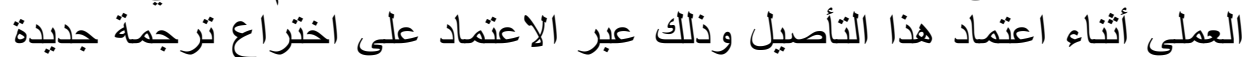

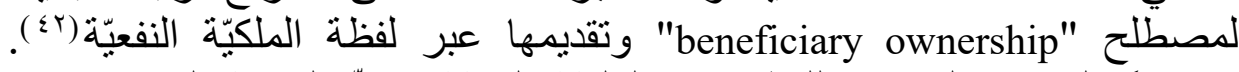

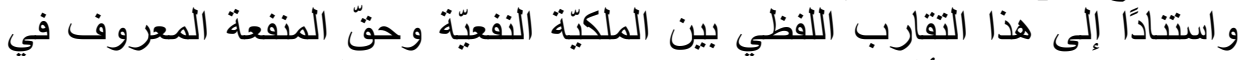

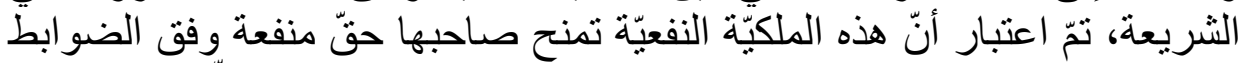

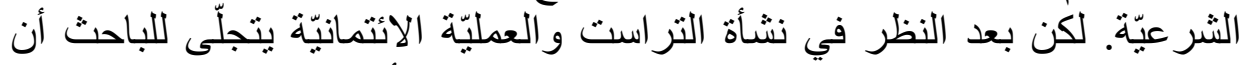

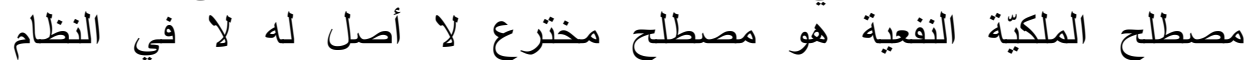

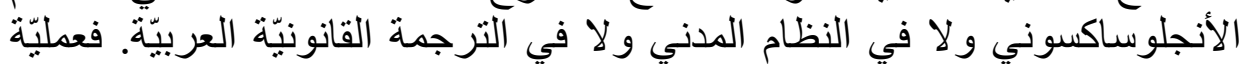

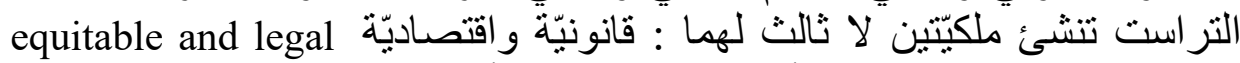

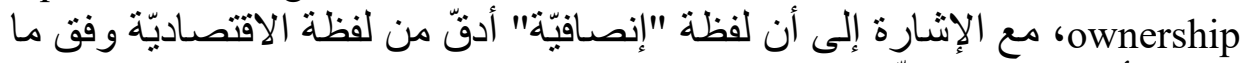

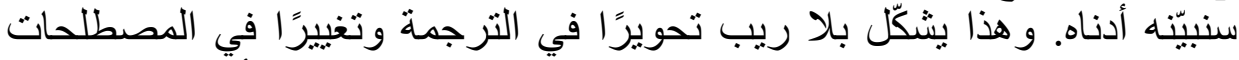

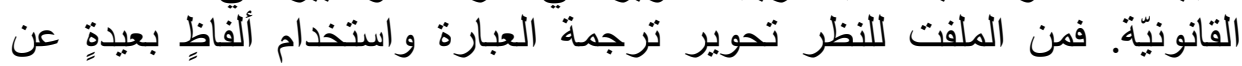

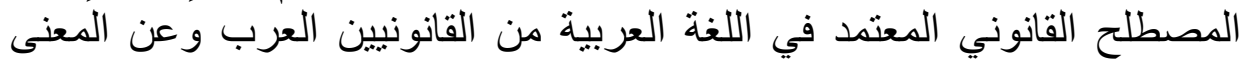
اللغوي والاصطلاحي المقصود من المصطلح الإنجليزي.

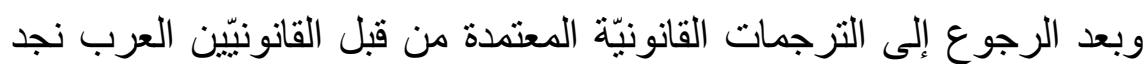

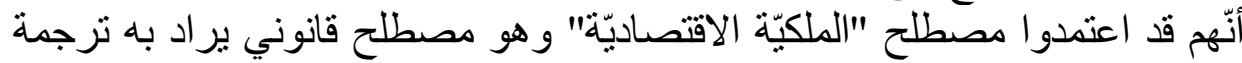

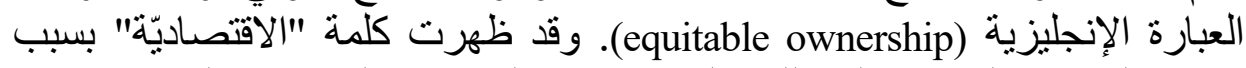

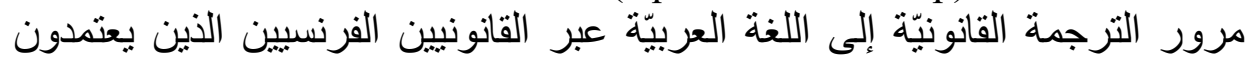

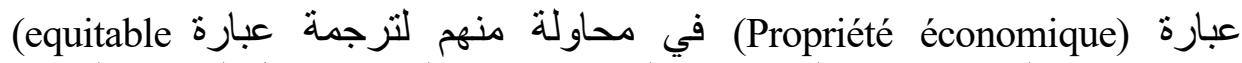
ownership)

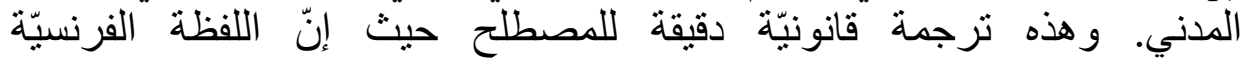

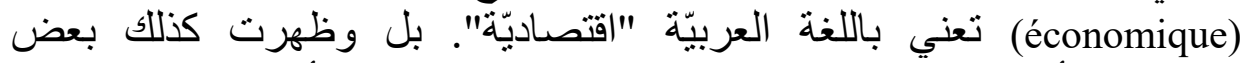

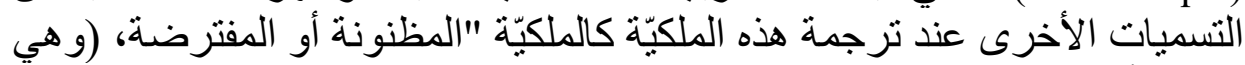

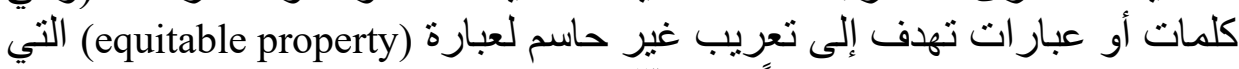
لم يعرف القانون الفرنسيّ مثيلاً لها)"("َّ). بينما لو قمنا بمقارنة المصطلح العربي العي

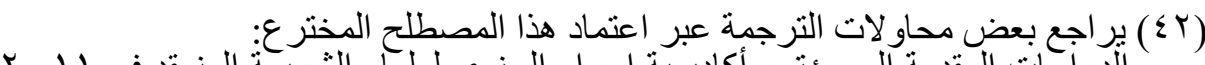

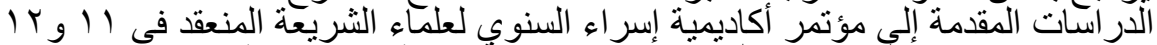

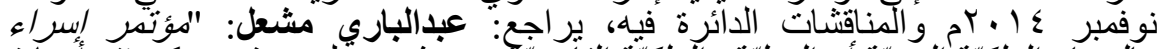

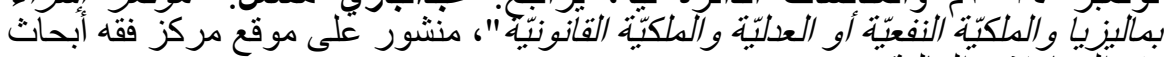

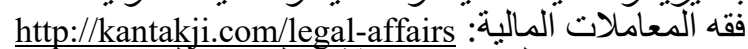

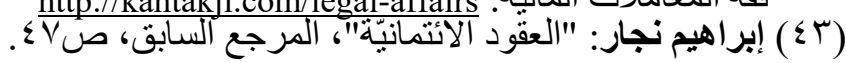


المتتمد بالأصل الإنجليزي فسنجد أن الترجمة قد أصبحت غير دقيقة. ويرجع

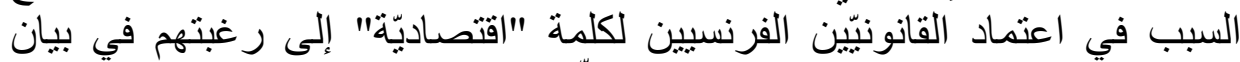

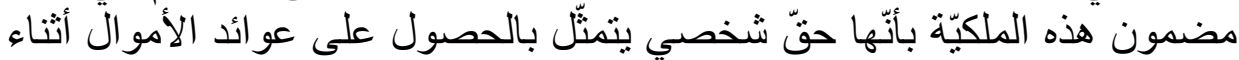
الاستثمار و استردادها مع نتائجها عند نهايته.

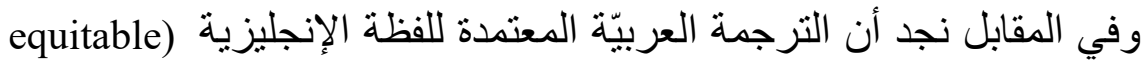

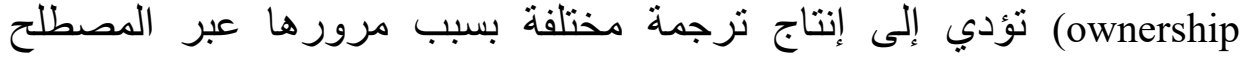

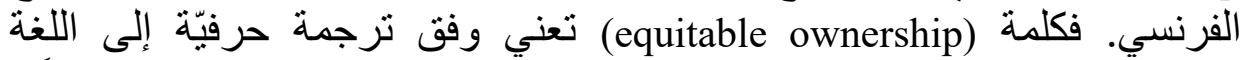
العربيّة "الملكيّة الإنصافية". و هذه الترجمة دقيقة ومطابقة لمنشأ اللفظة حيث إنى إنَّها

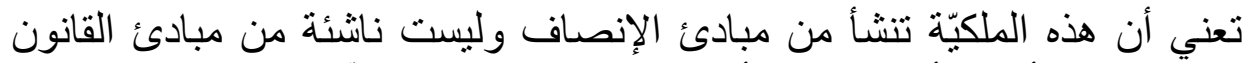

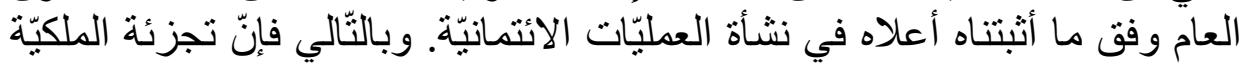

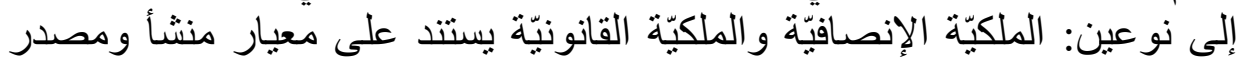

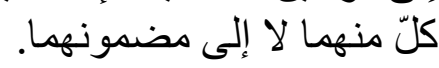

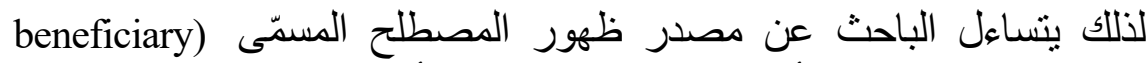

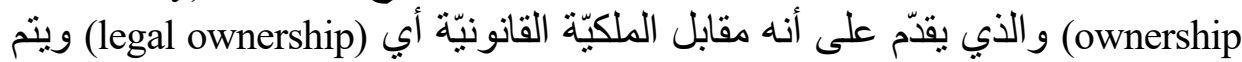

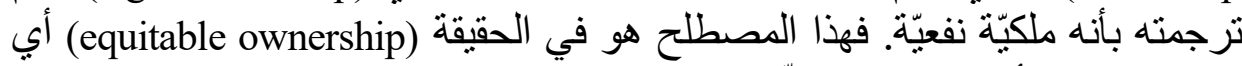

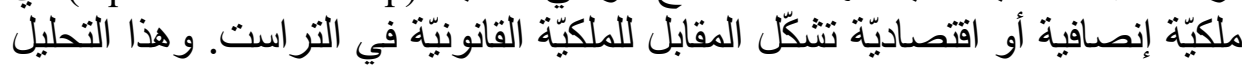

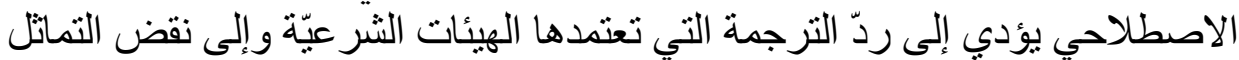

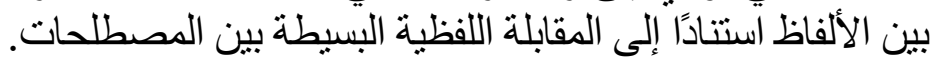

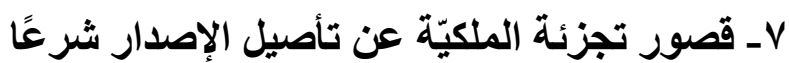

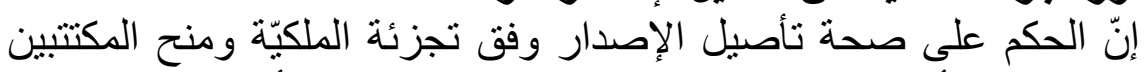

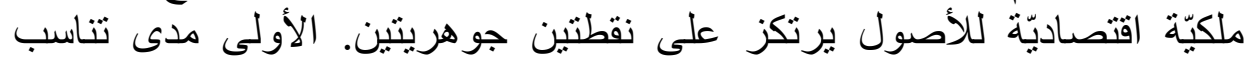

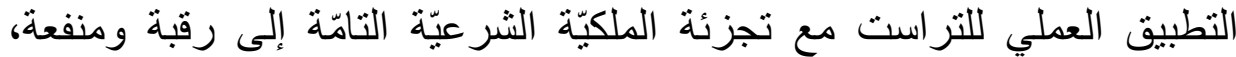

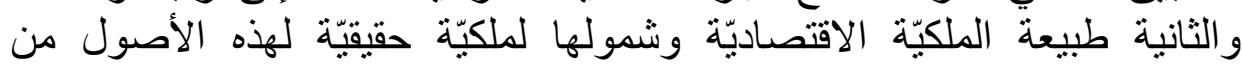

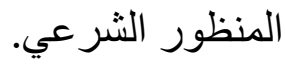

من جهة أولى، إنّ اقتراح تأصيل الإصدارات الماليّة الإسلاميّة على مبدأ

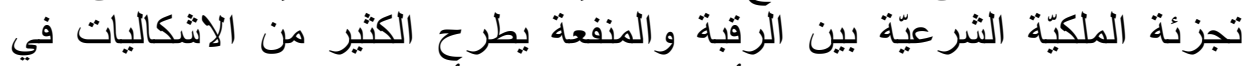

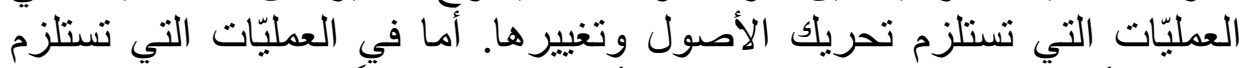

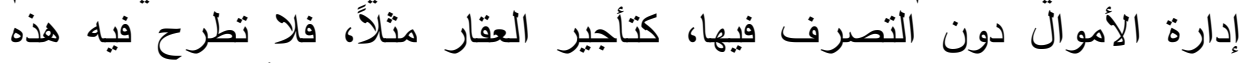

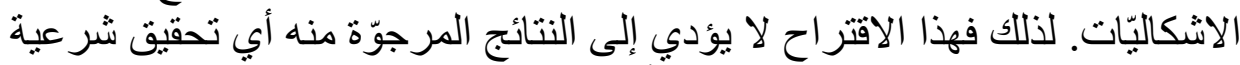

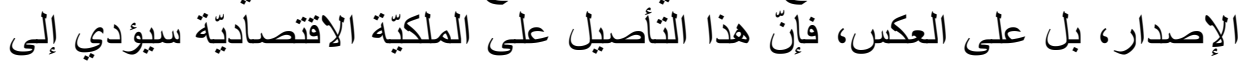


تناقض بين الأصل الشر عي المفترض و التعاملات التي تحصل. ويمكنتا أن نلخّص هذه التناقضات بما يأتي (« \&):

- - يحقّ للمدير مالك الرقبة وفق هذا الاقتر اح أن يقوم بكافة التصرفات القانونيّة

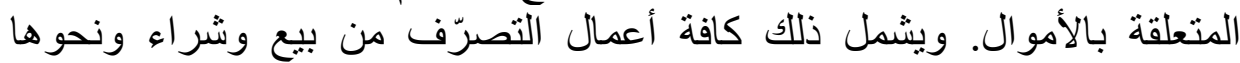

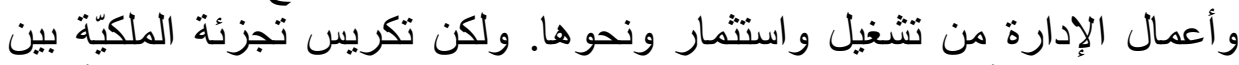

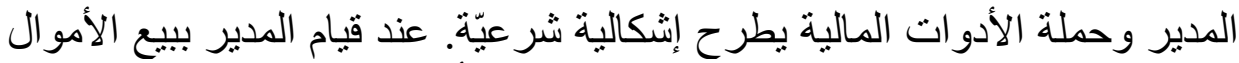

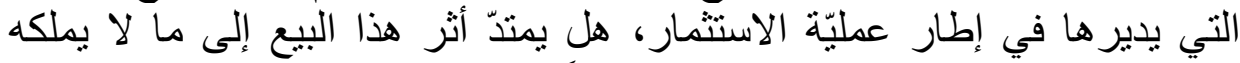

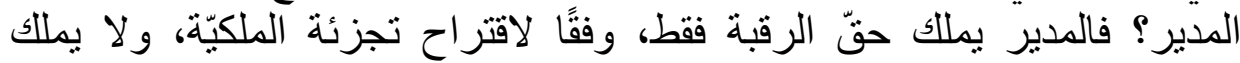

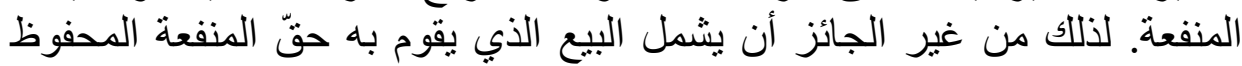

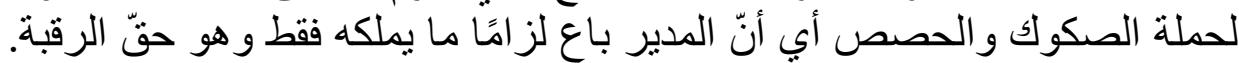

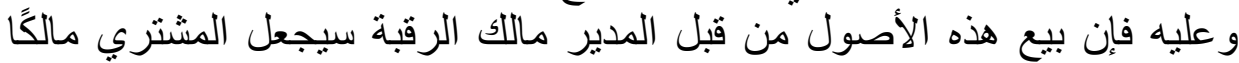
للرقبة فقط. وهذه النتيجة ليست منطقية لا من الناحية العمليّة ولا من الناحية

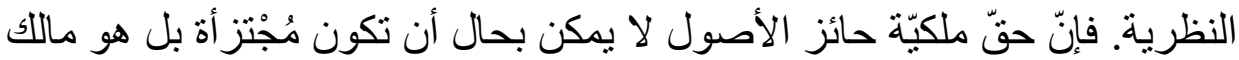

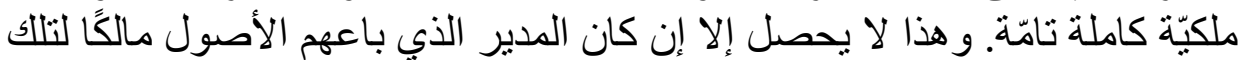
الملكيّة.

- - إنّ دخول أصول جديدة إلى المحفظة المالية يخضع للمبادئ العامّة للملكيّة.

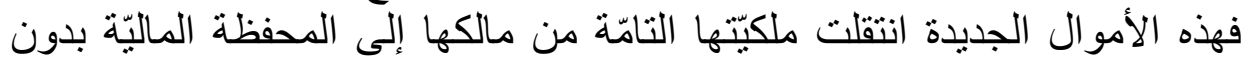

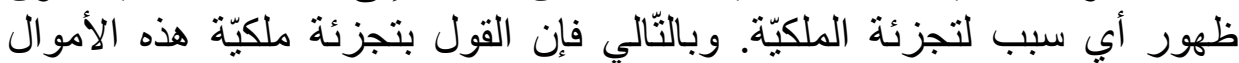

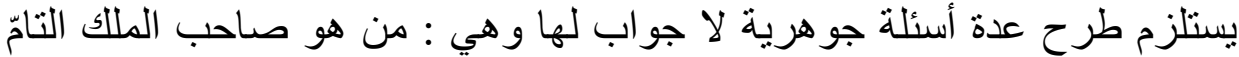

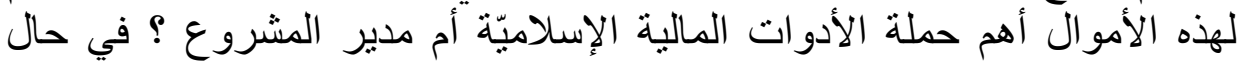

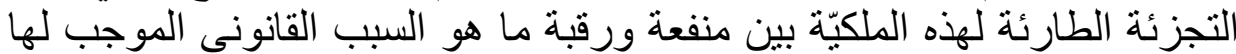

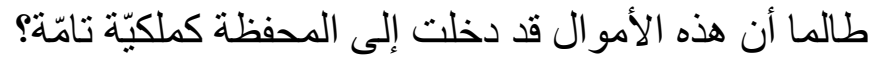

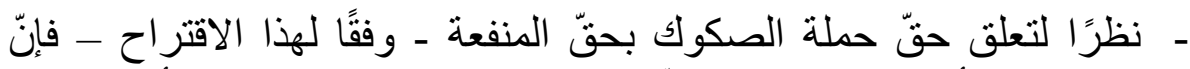

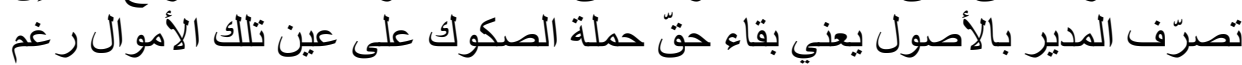

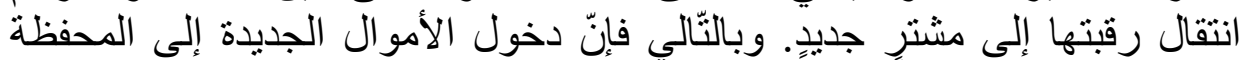

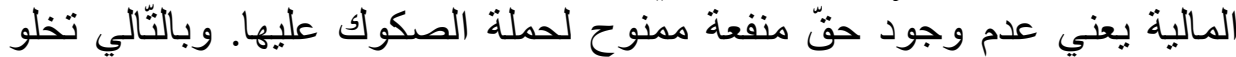

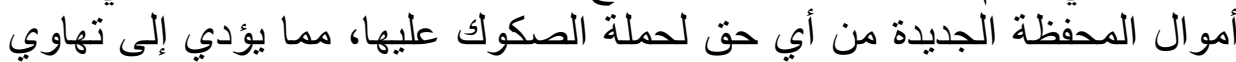

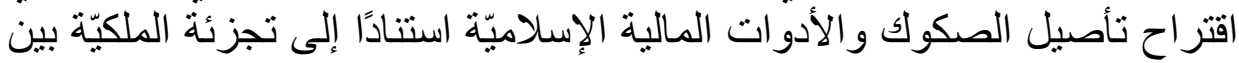

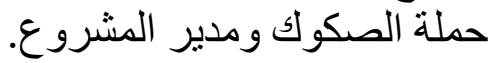

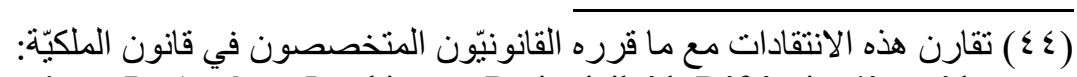
P. Malaurie et L. Aynès: «Les biens », Droit civil éd. Défrénois, 4ème éd. 2010, No. 760, p. 251. 
تؤكّد هذه الاعتر اضات الجو هرية على فنثل اقتر اح تجزئة الملكيّة بين منفعة المئة

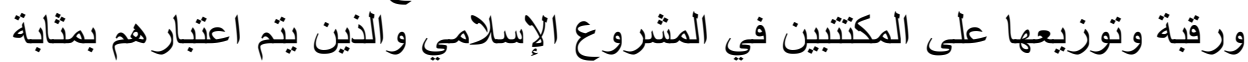

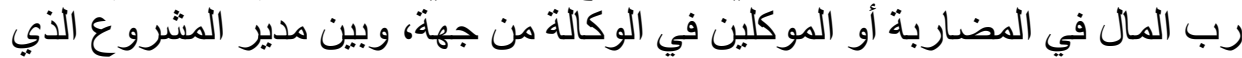

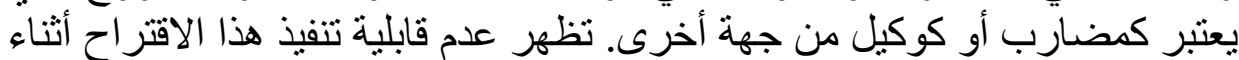

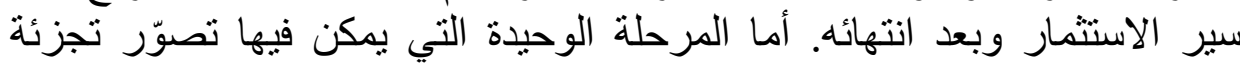

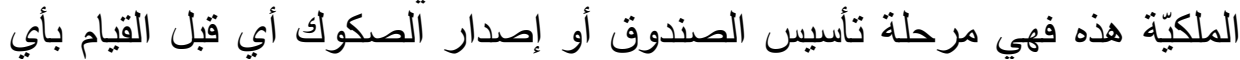

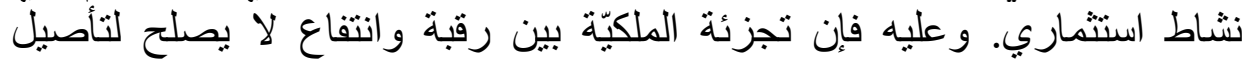
شر عية إصدار ات الصكوك وحصص وحص الصناديق الاستثمارية الإسلاميّة.

1ـ أثر عدم تمثيل الأوراق الماليّة للأصول

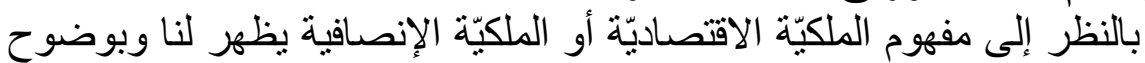

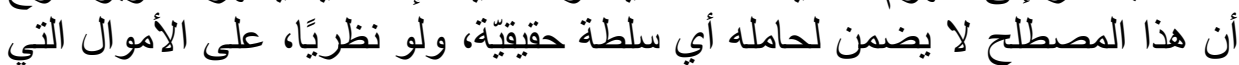

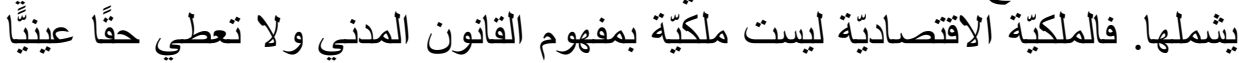

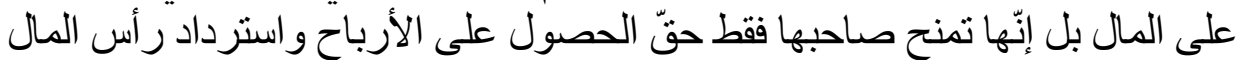

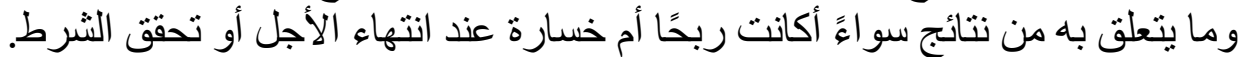

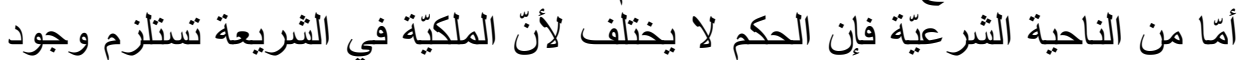

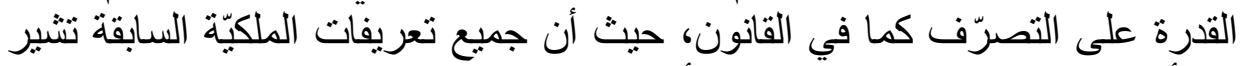
إلى أنها القدرة على التصرّف بالثرة فيء أو السلطة عليه.

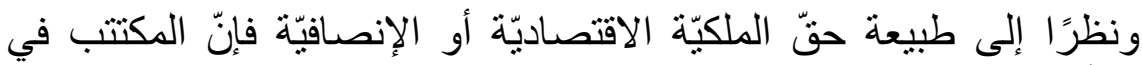

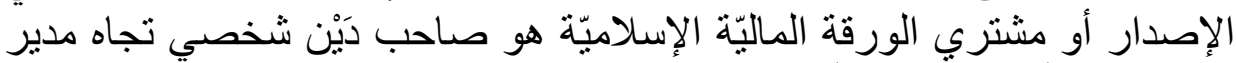

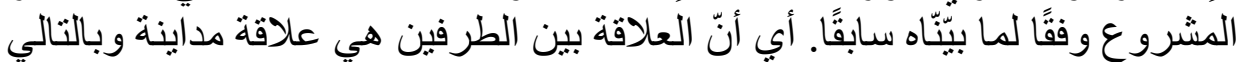

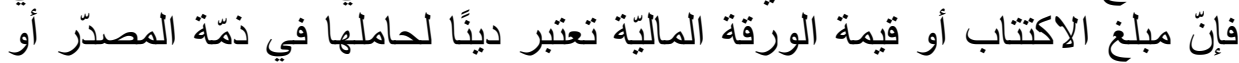

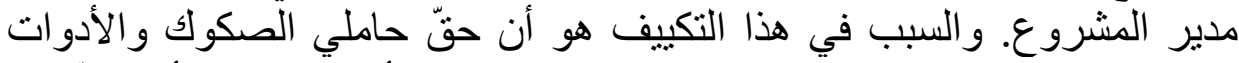

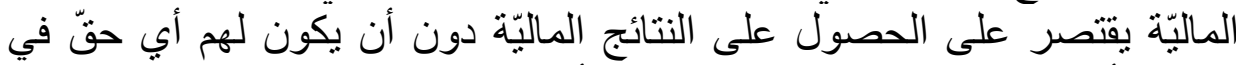

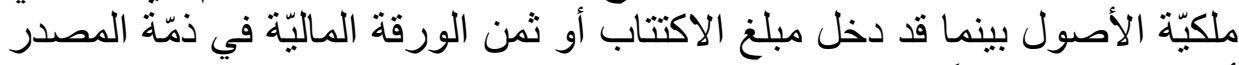
أو المدير فصنار دينًا عليه.

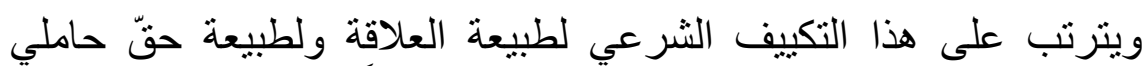

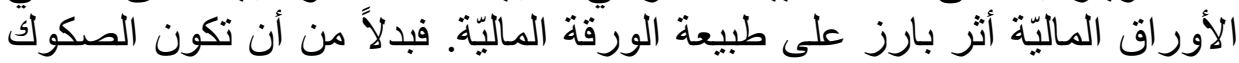

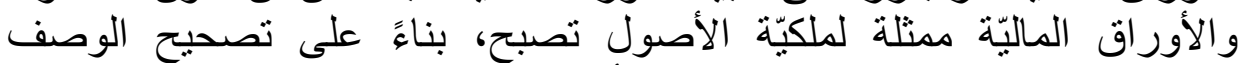

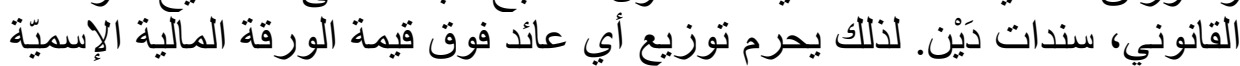

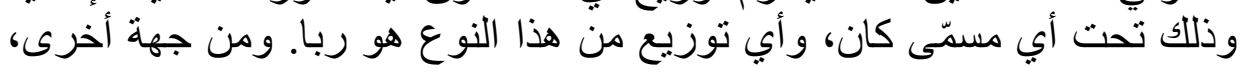




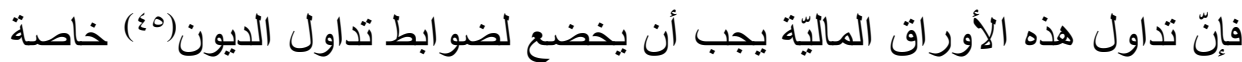

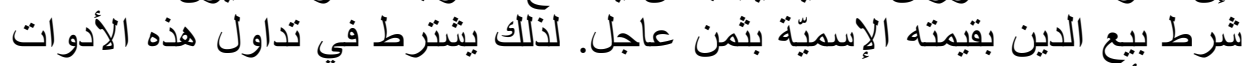

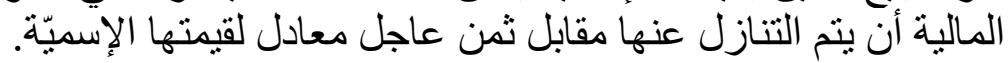

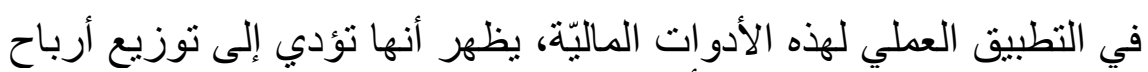

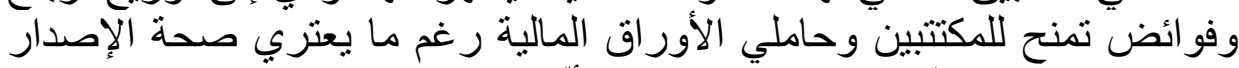

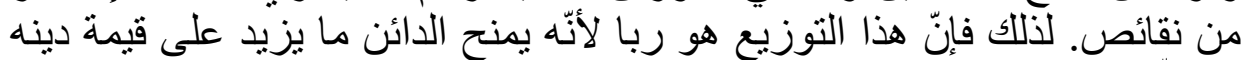

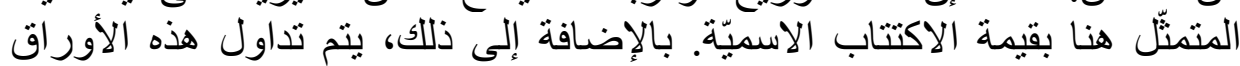

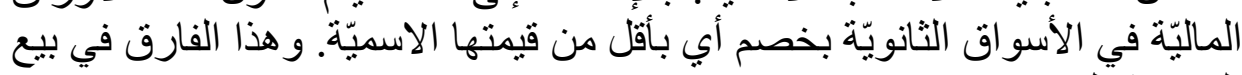

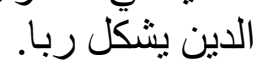

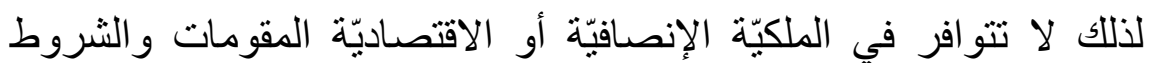

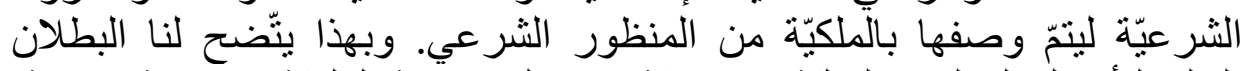

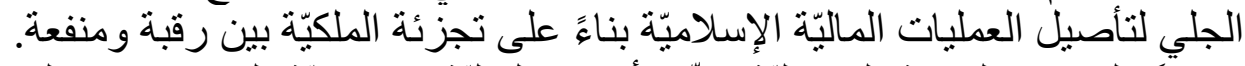

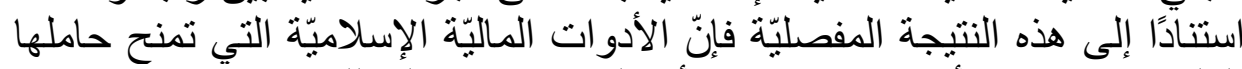

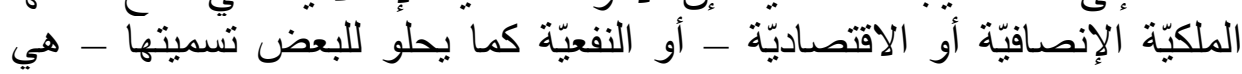
سندات دَيْنِ ربويَّة يحرم الاكتنتاب فيها.

(0) ير اجع حول شروط تداول الديون في الثريعة: محمد تقي العثماني: "بيع الدَّيْنِ و الأدوات الإديات

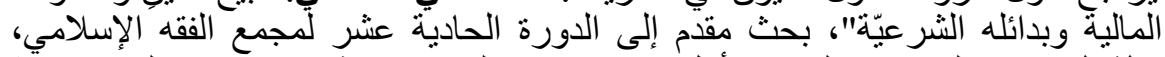

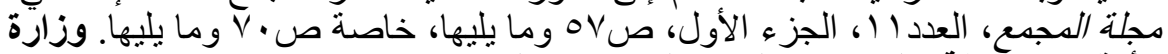

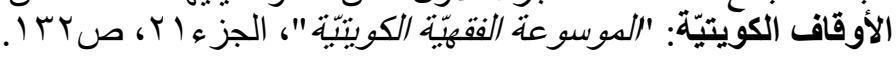




\section{الخاتمة}

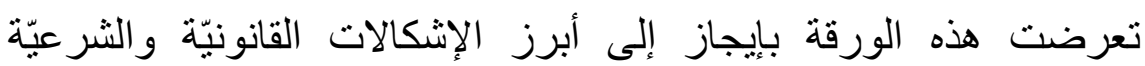

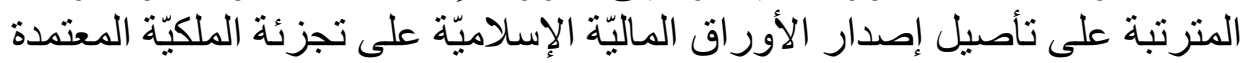

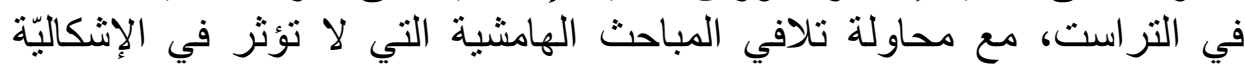
الأساس. وخلص البحث إلى ما يلّي:

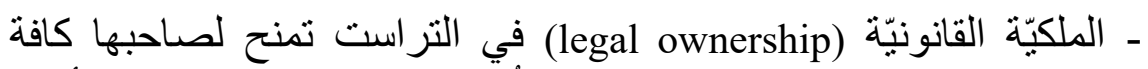

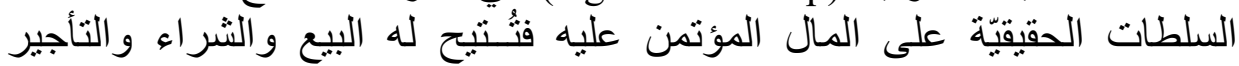
و الصيانة و غير ها من أعمال التصرف علف والإنهارة

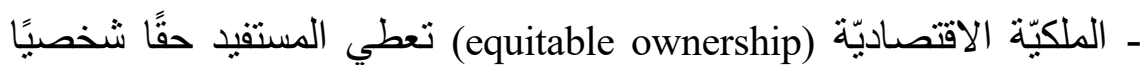

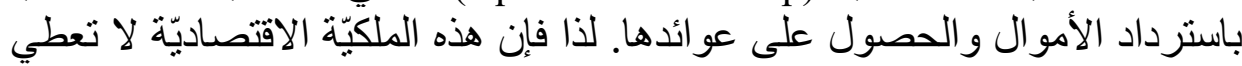

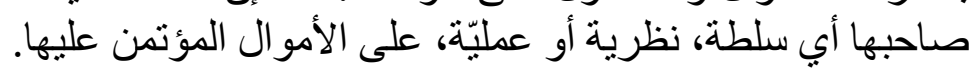

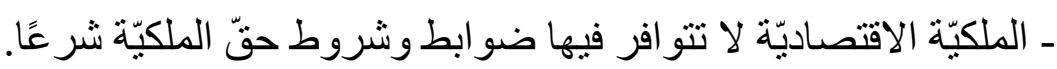
(equitable ownership) -

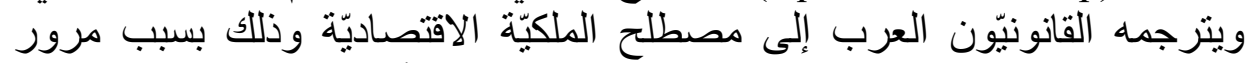

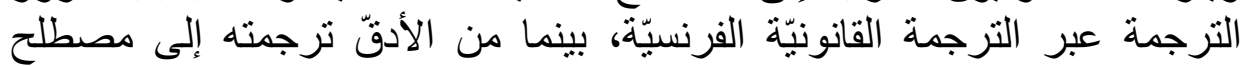

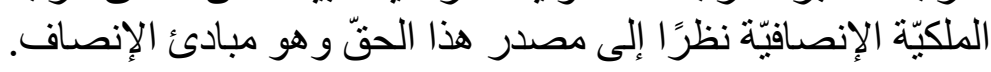

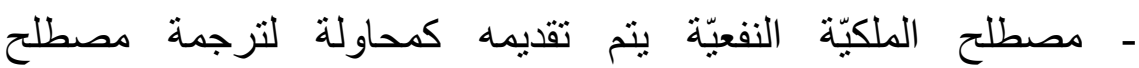
(beneficiary ownership)

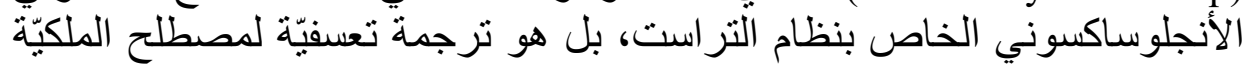

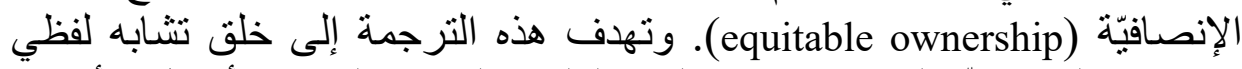

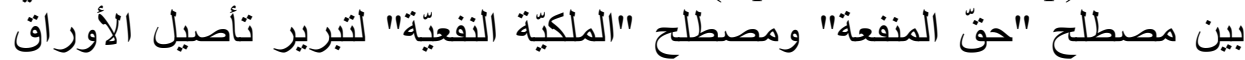

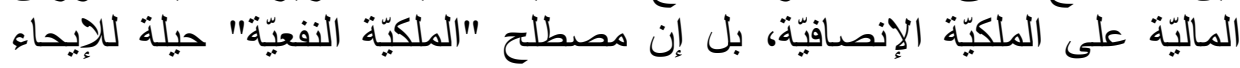

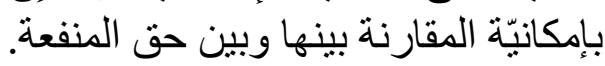

ـ محاولة بعض الهيئات الثرعيّة تأصيل الأدوات الماليّة على المئه الملكيّة

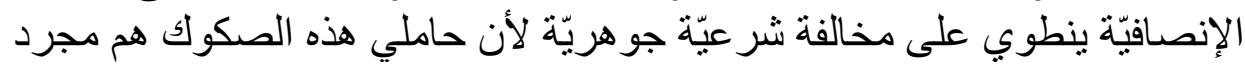

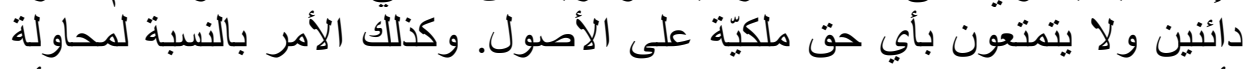

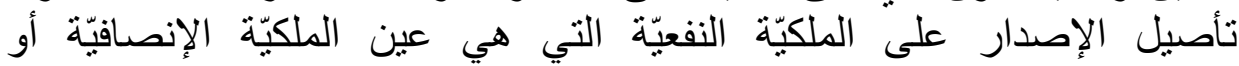
الاقتصاديّة.

ـ تقديم الملكيّة النفعيّة كمقابل لحق المنفعة يشكل مقارنة سطحية ولفظية.

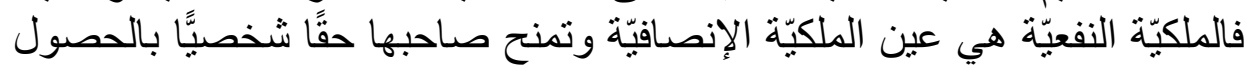


على النتائج ولا تعطي أيّ حقّ على الثيء، ولذا لا علاقة لها بمنفعة الأموال الائتمانيّة.

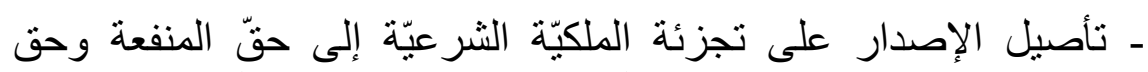

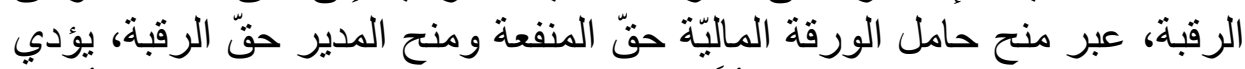

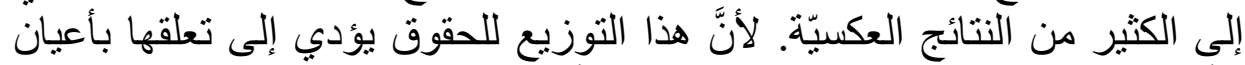

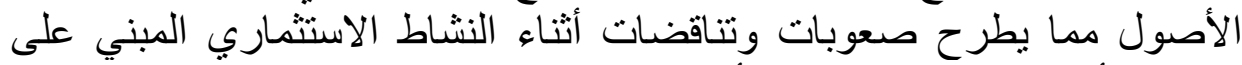

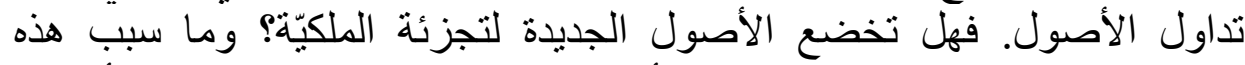

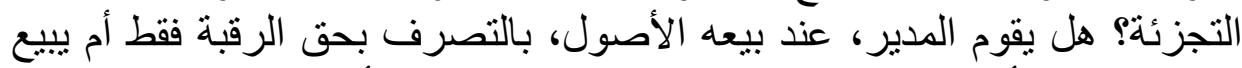

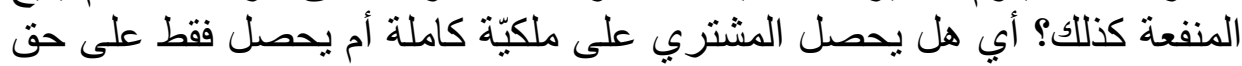

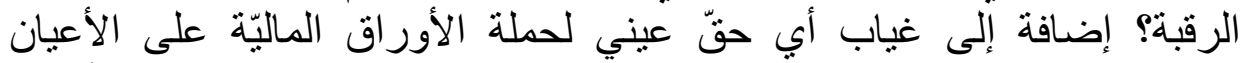

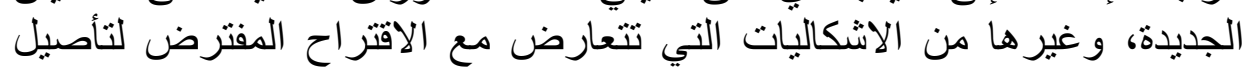

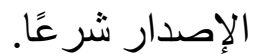

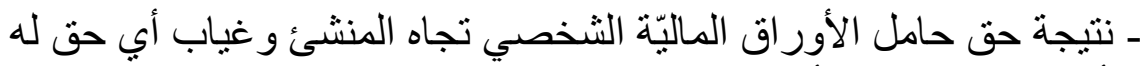

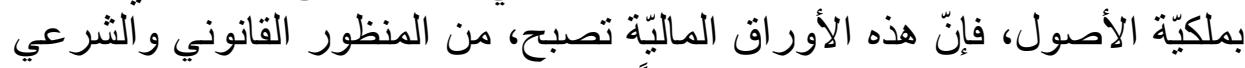

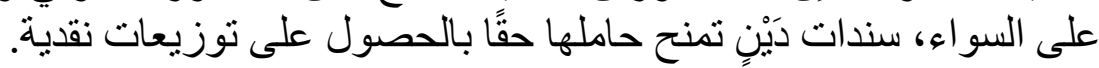

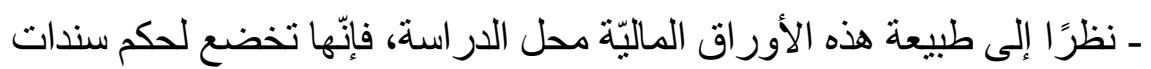

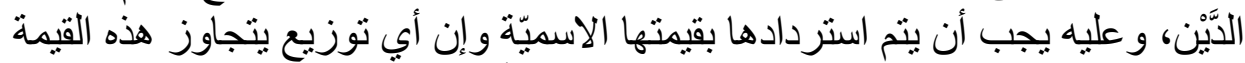

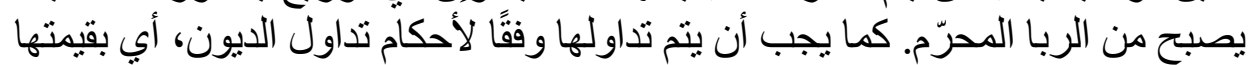

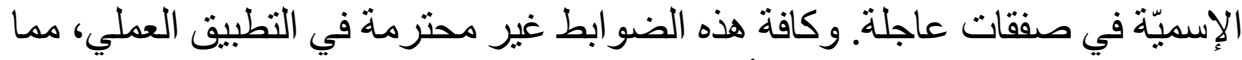
يحرّم الاكتتاب و الثراء في هذه فئه الأور اق الماليّة و التعامل بها.

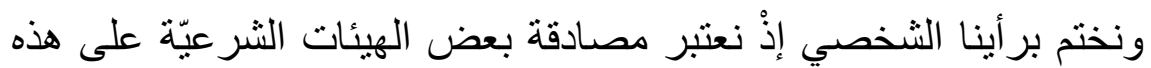

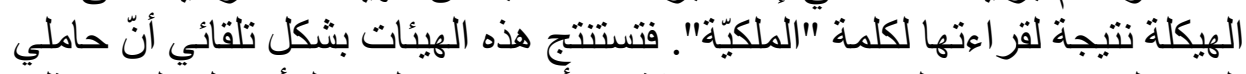

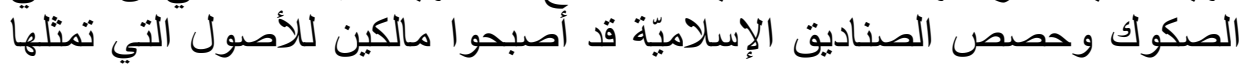

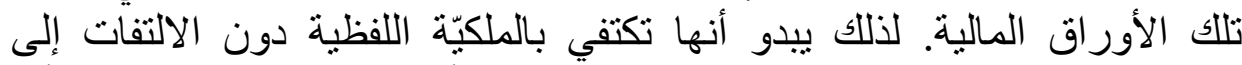

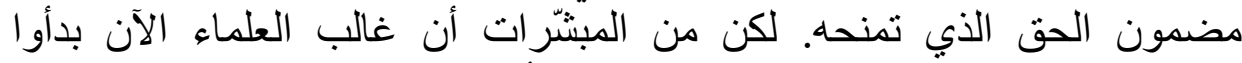
ينساعلون عن جديّة الملكيّة الاقتصاديّة وعن أثنر هذه العمليّة على جواز اليّة عمليّة

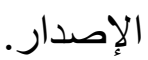

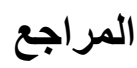

أوالاً: باللغة العربيّة

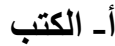

ابن تيمية، أحمد بن عبدالحليم، تقيّ الدين (7) إ(الهـ/990/م) "مجموع الفتاوى"، تحقيق

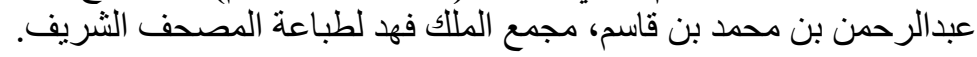


ابن الهمام، محمّل بن عبدالواحد، كمال الدين (د.ت.) "فتح القدير"، دار الفكر (• (ج)، ج.7،

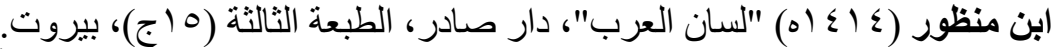

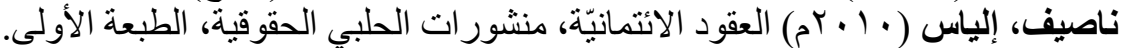

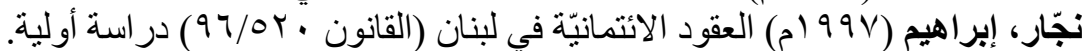

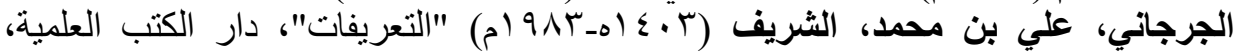

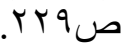

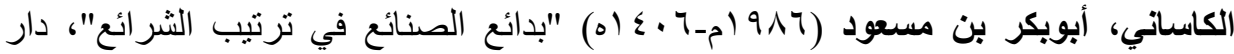

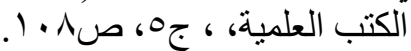

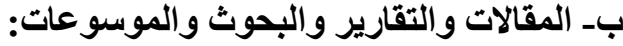

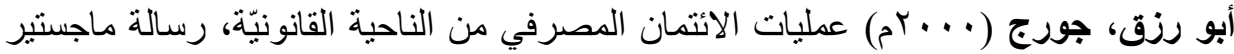

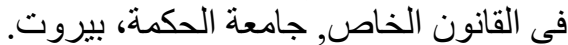

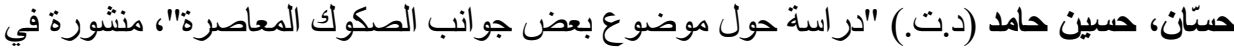

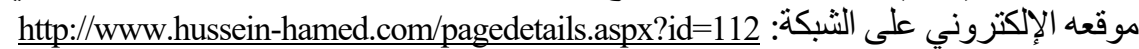

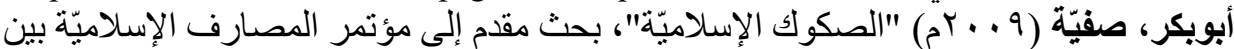

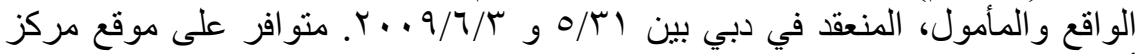
أبحاث فقه المعاملات المالية الإسلاميّة :

http://www.kantakji.com/fiqh/Files/Markets/m186.pdf

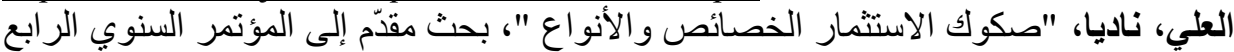

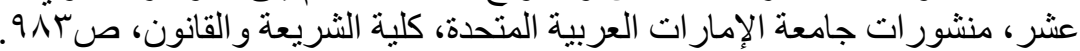

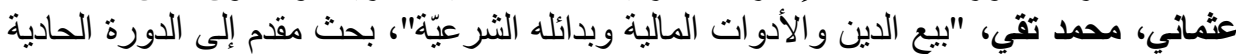

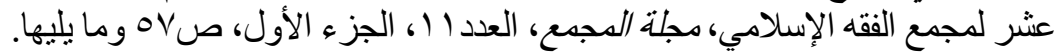

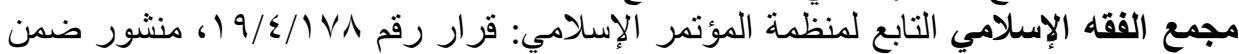

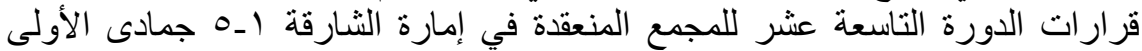

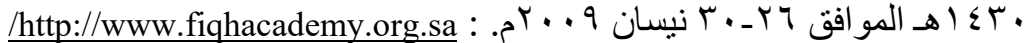
مشعل، عبدالباري، مؤتمر إسر اء بماليزيا و الملكيّة النفعيّة أو العدليّة و الملكيّة القانونيّة، منشور

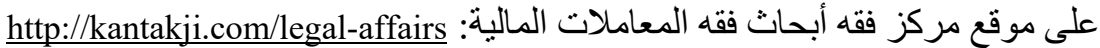

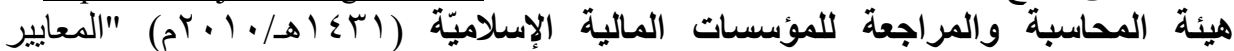

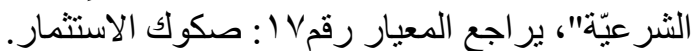

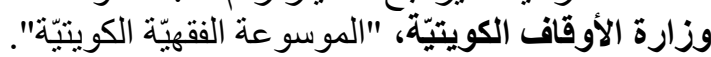

\section{A- Les ouvrages:} ثانيًاًا : باللغة الفرنيّة الفيّة

Jouaber-Snoussi, Kaouthar (2012) « La finance islamique », éd. La découverte Paris.

Lucas, François-Xavier (1997) «Les transferts temporaires des valeures mobilières, pour une fiducie de valeurs mobilières», préface de Louis Lorvellec, bibliothèque de droit privé, LGDJ.

Malaurie, Philippe et Aynès, Laurent (2010) « Les biens », Droit civil éd. Défrénois, $4^{\text {ème }}$ éd

\section{B- Les articles:}

Barrière, François: « Propriété, fiducie et sukuk », JCPE 2011.1203 
Champaud, Claude et Danet, Didier: «Sociétés et autre groupement», RTDCom 2007, p. 728.

Dergatcheff, Claire: «Droit comparé en matière de mécanismes fiduciaries: Pays anglo-saxons, Suisse, Luxembourg », in dossier Fiducie, JCPE 2007, 2060.

Dom, Jean-Philippe: «La fiducie-gestion et le contrat de société. Éléments de comparaison ", Rev. Soc. 2007, p.481.

Kaczmarek, Laurent: «Propriété fiduciaire et droit des intervenants à l'opération », D2009, 1845.

Larroumet, Christian: « La Loi du 19 février 2007 sur la fiducie, Propos critiques », in Dossier La Fiducie, D.2007, 1350.

Marini, Philippe: « La fiducie enfin », in Dossier: La fiducie, JCPE 2007،2050, N7

Marini, Philippe: «Enfin la fiducie à la française », in dossier La fiducie, D2007, 1347.

Servant-Schreiber, Pierre: «La fiducie: d'un moyen de gestion à une arme antiOPA? » in Dossier: La fiducie, JCPE 2007, 2055, et publiée en R.D.B.F. 2007, Études N19.

\section{Articles:}

Graziadei, Michele; Mattei, Ugo and Smith, Lionel: « Commercial Trusts in European Private Law », Cambridge University Press, p.7. On line: http://assets.cambridge.org/97805218/49197/excerpt/9780521849197 excerpt.pdf

Gretton, Georges: «Trust Without Equity», International and Comparative Law Quarterly (ICLQ), vol.49, July 2000, p.599.

Maitland, Frederic William: « Equity, a course of lectures », Cambridge Univ. Press, 1936, $2^{\text {nd }}$ éd., p. $17 \&$ p. 112.

Waters, Donovan William Mockford «The Nature of the Trust Beneficiary's Interest », 45 Can. Bar Rev., 1967, 219, p. 280. 


\title{
The Legitimacy of Islamic Issuances based on Degradation of Ownership
}

\author{
Mohyedine HAJJAR \\ Financial Law Researcher, Panthéon-Sorbonne University \\ Lecturer, New Sorbonne University
}

\begin{abstract}
This paper provides a common basis for discussion between lawyers and Islamic scholars about some legal and Islamic concepts affecting the Islamic finance industry. Some forms of Islamic finance instruments issuances and their engineering are still the subject of debate big controversy, especially issuances whose structuring is based on degradation of ownership as it is adopted in the Anglo-Saxon trust. Therefore the main question that arises from this debate is: Could we consider Islamic financial instruments' holders as 'real' owners of the assets on the basis of their equitable ownership that exists in the Trust laws?
\end{abstract}

To address this question, the paper presents the emergence of fiduciary transactions and origin of the degradation of the ownership in Trust operations and the definition of the content of legal and equitable ownership. Equitable ownership is a personal right that entitles 'the owner' of possessing assets and all their results, while the legal ownership includes all the legal powers given to the owner. Due to obligation of considering the Islamic financial instruments' holders as owners of assets, issues of Islamic financial instruments that give operators an equitable ownership form a violation of Islamic legal norms. As for any attempt of basing Islamic financial instruments by giving their operators a usufructuary ownership, it requires analysis of this term and a presentation of its origin. In fact, there is an arbitrary and inaccurate translation of the term «equitable ownership». Therefore, the degradation of the ownership that is adopted from Trust law cannot provide a suitable legal framework for the issuances of Islamic financial instruments. This is so, because majority of the 'Islamic' instruments have become conventional debt securities and their revenues have become a prohibited ribā.

Keywords: Financial instruments, Șukūk, Equitable ownership, Legal ownership. 


\section{د. محيي الدين عدنان الحجار}

دكتوراه في القانون المالي من جامعة السوربون (باريس () ودكتوراه في تاريخ

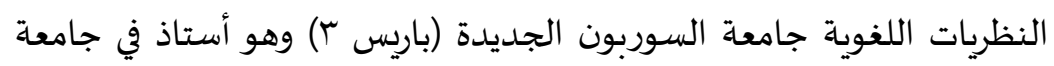

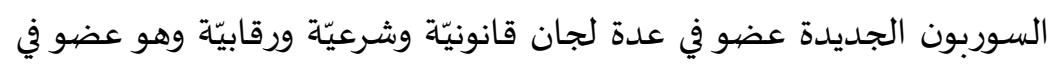

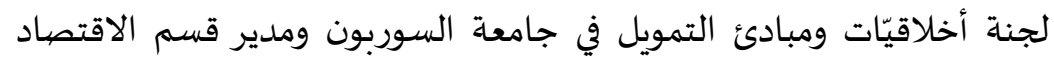

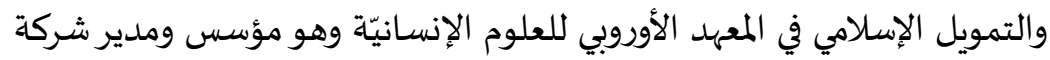

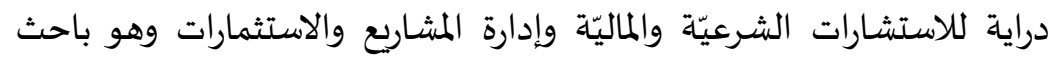
أكاديمي متخصص في قانون العقود والشركات والقانون المالي والمعاملات الإسلاميّة والنظام القانوني لعمليّات الاقتصاد والتمويل الإسلامي وخبير في

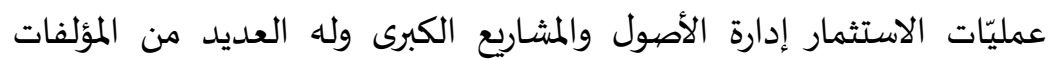
والمقالات. البريد الإلكتروني: والت 